\title{
Physiological and Biochemical Responses of Forage Grass Varieties to Mild Drought Stress Under Field Conditions
}

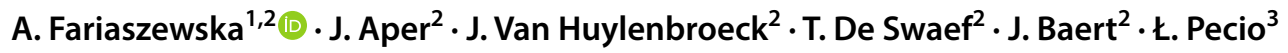

Received: 28 May 2019 / Accepted: 16 January 2020 / Published online: 22 January 2020

(c) The Author(s) 2020

\begin{abstract}
In view of the expected increase in drought periods, researchers and breeders are searching for forage grasses that are more tolerant to drought stress. This study wanted to examine the physiological and biochemical reactions of nine forage grass varieties belonging to Festuca, Lolium and Festulolium under mild drought stress conditions in a semi-controlled field experiment. A mild drought stress treatment was applied in the period between cut II and cut III using three large mobile rain-out shelters equipped with sprinkler irrigation systems. The experiment consisted of two soil moisture treatments: (1) control where a soil moisture level of around $20 \% \mathrm{v} / \mathrm{v}$ was maintained and (2) drought stress where the soil moisture level decreased to $7.5 \% \mathrm{v} / \mathrm{v}$. The experiment was cut 5 times in 2014 and 4 times in 2015. A total of nine varieties from five species of forage grasses were evaluated: L. perenne, L. multiflorum, F. pratensis, F. arundinacea and F. braunii. Dry matter yield, gas exchange parameters and chlorophyll fluorescence were significantly lower in drought stress than under control conditions and the physiological parameters reacted within 2 weeks after the start of the drought treatment in all species. In contrast, drought stress significantly increased water use efficiency, the content of proline, phenolic acids, flavonoids, water soluble carbohydrates and decreased neutral and acid detergent fibre on both years. Based on total dry matter yield and tolerance indices the most drought tolerant species were L. multiflorum in the first and $F$. arundinacea in the second investigated year.
\end{abstract}

Keywords Drought stress $\cdot$ Forage grasses $\cdot$ Rain-out shelter $\cdot$ Photosynthesis $\cdot$ Proline $\cdot$ Phenolic compounds

\section{Introduction}

Increased frequency and intensity of drought events are among the main effects of climate change and global warming. Water deficit mainly causes reduced crop yields and inhibits their development, which is related to series of morphological, physiological and biochemical changes in plant tissue. The loss of yield and survival of crop plants depends on duration and intensity of water stress (Bahrani et al. 2010; Abbasi et al. 2014). Physiological responses may depend on

A. Fariaszewska

anna.fariaszewska@gmail.com

1 Department of Forage Crop Production, Institute of Soil Science and Plant Cultivation-State Research Institute (IUNG), Puławy, Poland

2 Plant Sciences Unit, Research Institute for Agriculture, Fisheries and Food (ILVO), Melle, Belgium

3 Department of Biochemistry and Food Quality, Institute of Soil Science and Plant Cultivation-State Research Institute, Puławy, Poland plant genotype, but in general, reactions related to drought stress include reduction of $\mathrm{CO}_{2}$ assimilation rate, stomatal conductance and photosynthetic efficiency of photosystem II (PSII). PSII shows considerable sensitivity to water stress: the photosynthetic electron transport through PSII is inhibited and oxygen involving complex of PSII and PSII reaction centres are damaged (He et al. 1995; Lu and Zhang 1999). One of the best known reaction of drought stress is a closure of stomata to avoid loss of water through the transpiration process (Cornic 1994; Lawlor 2002; Hura et al. 2007). Many studies also confirm an increase of osmoprotectants, such as proline, glycine betaine, alcohols and sugars (Bates et al. 1973; Sairam et al. 2002). These components prevent the loss of water from the cells by decreasing the osmotic potential (Bray 1993, 1997). The increase of some secondary metabolites like phenolic compounds under drought stress conditions is often observed in plants and could be an important strategy to cope with the adverse effects of water deficit (Jaafar et al. 2012). They have a strong radical scavenging activity contributed to the minimization of oxidative and drought stress in relation to the photosynthesis apparatus 
(Kikuzaki et al. 2002; Nakabayashi et al. 2014). Lolium perenne, one of the most important forage grass species in Northwestern Europe, is susceptible to drought stress and the increase in drought periods triggered researchers to find out the responses of species and varieties of forage grasses to water deficit. The knowledge of tolerance strategies to changing water availability makes a targeted selection of drought tolerant genotypes possible. Studies under highly controlled conditions in pots allow a detailed evaluation of the physiological reaction of plants to drought, but there is a need for an extrapolation of these results to the field (Fariaszewska et al. 2016). In order to identify drought tolerant genotypes, many indices recommended on the basis of yield under non-stress and drought stress conditions exist. The Stress Tolerance Index (STI) is one of the most useful indices to recognize tolerant genotypes (Fernandez 1992).

The main aims of this study were (1) to evaluate the response of varieties of different grass species to drought by measuring dynamics and changes in yield, forage quality, gas exchange parameters, chlorophyll fluorescence, accumulation of proline and phenolic compounds during two years in a rain-out shelter experiment and (2) to compare the obtained results from this semi-controlled field experiment with the results of an earlier published pot experiment where root growth was restricted (Fariaszewska et al. 2016).

\section{Materials and Methods}

\section{Plant Material}

Nine varieties of forage grasses were evaluated in the field experiment: Lolium perenne 'Melluck' $(2 \mathrm{n}=2 \mathrm{x})$, 'Meltador' $(2 \mathrm{n}=4 \mathrm{x})$, Lolium multiflorum 'Meldiva' $(2 \mathrm{n}=2 \mathrm{x})$, 'Melmia' $(2 \mathrm{n}=4 \mathrm{x})$, Festuca pratensis 'Merifest' $(2 \mathrm{n}=2 \mathrm{x})$, 'Merifest Tp' $(2 \mathrm{n}=4 \mathrm{x})$, Festuca arundinacea 'Barolex' $(2 \mathrm{n}=6 \mathrm{x})$, 'Callina' $(2 \mathrm{n}=6 \mathrm{x})$ and Festulolium braunii 'Felopa' $(2 n=4 x)$. These varieties were the same varieties that were used in a Mitscherlich pot experiment under controlled conditions (Fariaszewska et al. 2016).

\section{Experimental Design}

A split-plot experimental design was installed in a field with three mobile rain-out shelters at the Institute for Agricultural and Fisheries Research (ILVO) in Melle

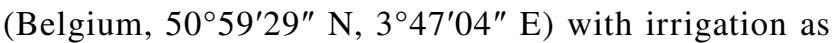
whole-plot factor and variety as split-plot factor. The soil had a sandy loam texture with $76 \%$ sand, $16 \%$ silt and $8 \%$ clay and contained $1.6 \% \mathrm{C}$ with a $\mathrm{pH}-\mathrm{KCl}$ of 5.73 . One shelter covered an area of $300 \mathrm{~m}^{2}(30 \mathrm{~m} \times 10 \mathrm{~m})$ and served as one replicate. Each shelter was split into two parts (drought-control) of $150 \mathrm{~m}^{2}(15 \mathrm{~m} \times 10 \mathrm{~m})$ and each part had its own sprinkler irrigation system. One part contained twelve plots in an arrangement of three rows $\times$ four columns and was surrounded by border plots. The nine varieties used in the experiment were randomised over this twelve plots and the three remaining plots were used for breeding populations and were not included in this study. The plots were sown with an Oyord sowing machine on 2 October 2013. One plot had a surface of $3.1 \mathrm{~m}^{2}(2.3 \mathrm{~m}$ $\times 1.35 \mathrm{~m}$ ) after trimming and contained 10 rows with a distance of $13.5 \mathrm{~cm}$ between the rows. The sowing density was 1000 viable seeds per $\mathrm{m}^{2}$.

All grasses were cut five times in 2014 (5 May, 6 June, 17 July, 5 August and 25 September) and four times in 2015 (21 May, 25 June, 3 August and 1 October). We only harvested four cuts in 2015 because the first cut in 2015 started later due to a colder winter and spring (Fig. 1). The plots were fertilised in 2014 with $81+100 \mathrm{~kg} \mathrm{~N}+\mathrm{K} \mathrm{ha}^{-1}$ before cut I, $68+10+83 \mathrm{~kg} \mathrm{~N}+\mathrm{P}+\mathrm{K} \mathrm{ha}^{-1}$ after cut I, $68+33 \mathrm{~kg} \mathrm{~N}+\mathrm{K} \mathrm{ha}^{-1}$ after cut II, $39+8+57 \mathrm{~kg} \mathrm{~N}+\mathrm{P}+\mathrm{K} \mathrm{ha}^{-1}$ after cut III and $41 \mathrm{~kg} \mathrm{~N}$ $\mathrm{ha}^{-1}$ after cut IV and in 2015 with $81+100 \mathrm{~kg} \mathrm{~N}+\mathrm{K} \mathrm{ha}^{-1}$ before the cut $\mathrm{I}, 59+12+86 \mathrm{~kg} \mathrm{~N}+\mathrm{P}+\mathrm{K} \mathrm{ha}^{-1}$ after cut I, $68+33 \mathrm{~kg} \mathrm{~N}+\mathrm{K} \mathrm{ha}^{-1}$ after cut II and $52+11+76 \mathrm{~kg} \mathrm{~N}+\mathrm{P}+\mathrm{K} \mathrm{ha}^{-1}$ after cut III using a Rauch pneumatic fertiliser spreader. There were no pesticides used during the experiment.

A mild drought stress treatment was realised by covering the trial with the rain-out shelters in the period between cut II and cut III. Coverage period was between 11 June-14 July in 2014 and 1 July-3 August in 2015. The drought treatment was between 13 June and 14 July in 2014 and between 3 July and 3 August in 2015. The field experiment consisted of two soil moisture treatments: in the control treatment a soil moisture level of around $20 \%$ v/v (just above field capacity, Fig. 2) was obtained using the irrigation system, while in the drought stress treatment plants were only irrigated when the soil moisture level was less than $7.5 \% \mathrm{v} / \mathrm{v}$. No irrigation was used beside the coverage period. The irrigation water was ground water with a $\mathrm{pH}$ of 6.9 and an EC of $0.482 \mathrm{mS} \mathrm{cm} \mathrm{cm}^{-1}$. Volumetric water content was measured hourly using 48 time domain reflectometry (TDR) sensors (type CS616, Campbell Scientific Inc., UK) installed in the plots. The two-pronged sensors made of stainless steel were $30 \mathrm{~cm}$ long and $3.2 \mathrm{~mm}$ in diameter, and were installed vertically at a depth of $10 \mathrm{~cm}$ in the soil. Data were collected using a datalogger and multiplexer (type CR1000 + AM16/32, Campbell Scientific Inc., UK) and LoggerNet software. 
Fig. 1 Average monthly temperatures and precipitation in 2014-2015 and over the last 20 years in Merelbeke (Belgium)

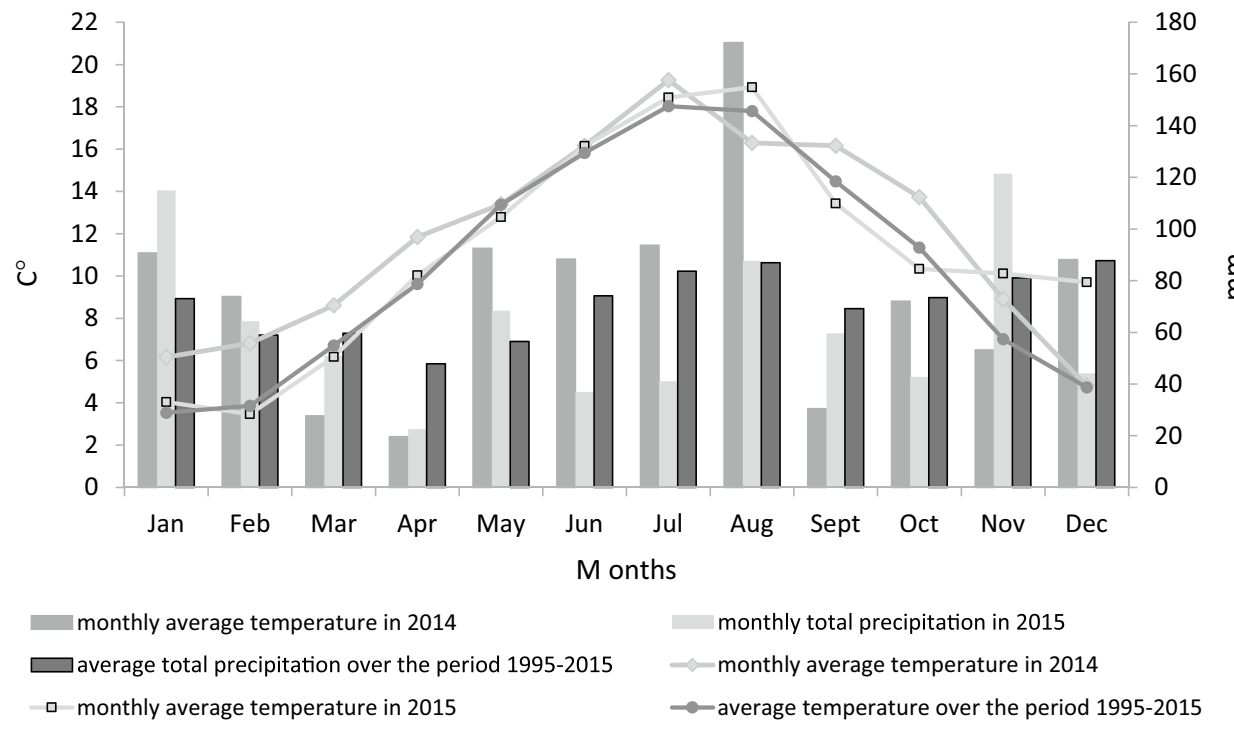

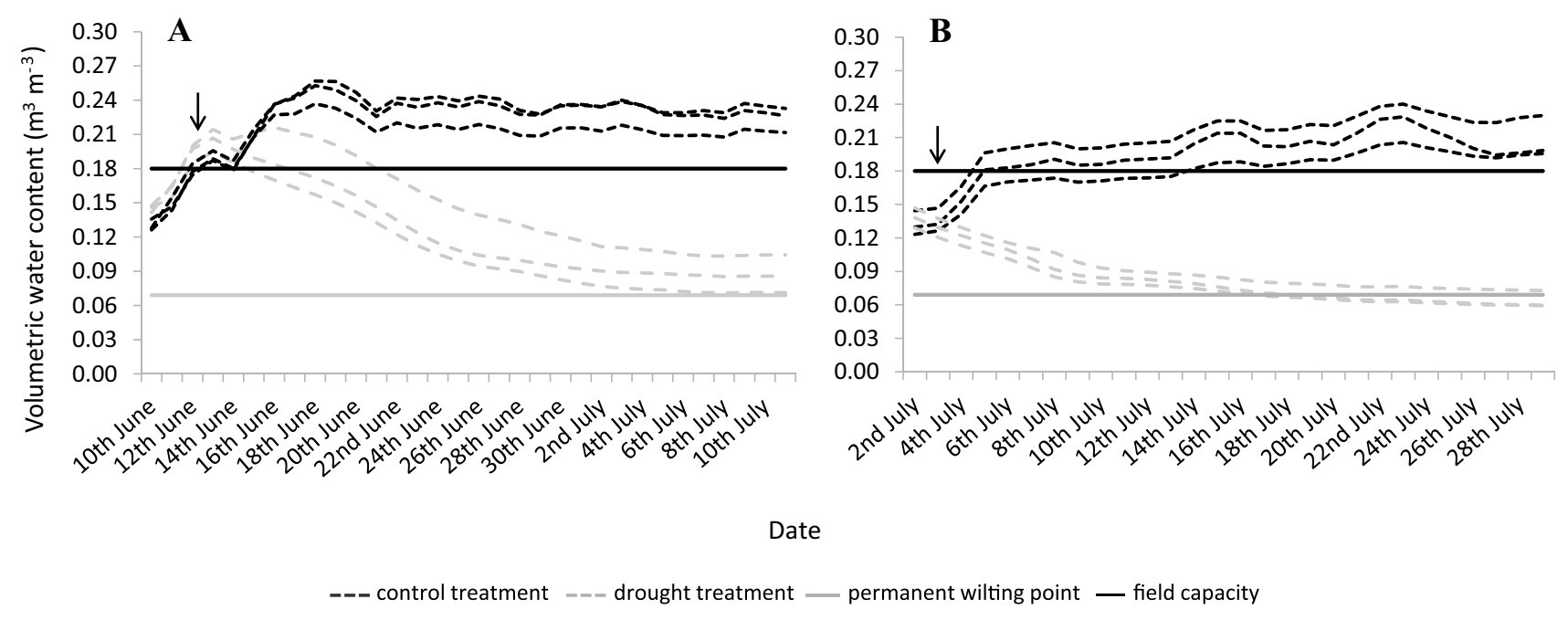

Fig. 2 Changes in volumetric water content at the 0-30 cm soil depth between cut II and cut III in 2014 (a) and 2015 (b). The arrow in the figures indicate the date when the drought treatment started

\section{Climatology data}

Monthly rainfall totals and mean temperatures for each month in 2014-2015 and over the last 20 years are based on the data at the meteorological station in Merelbeke $\left(50^{\circ} 59^{\prime} 40^{\prime \prime} \mathrm{N}\right.$, $3^{\circ} 44^{\prime} 46^{\prime \prime} \mathrm{E}$ ) (Fig. 1). In 2015, lower temperatures were recorded in late winter and spring in comparison with 2014. In general, summer (June, July and August) was much drier in 2015 than in 2014.

\section{Measurements}

\section{Dry Matter Yield and Dry Matter Content}

Dry matter yield $\left(10^{3} \mathrm{~kg} \mathrm{ha}^{-1}\right)$ and dry matter content $(\%)$ were measured at each cut. Plots were mown and fresh weight was determined using a plot harvester (Haldrup, Løgstør, Denmark) and a sample of $200 \mathrm{~g}$ of fresh plant material was taken to estimate the dry matter content. 
The Stress Tolerance Index (STI) was calculated using the following relationship (Fernandez 1992):

$S T I=\frac{Y p \cdot Y s}{M p^{2}}$

In the above equation, $\mathrm{Yp}, \mathrm{Ys}$ and $\mathrm{Mp}$ represent the yield of each variety in non-stress conditions, the yield in stress conditions and the average yield of varieties in non-stress conditions, respectively. We used the total annual dry matter yield to calculate the STI for 2014 and 2015.

\section{Gas Exchange Parameters}

During the drought treatment period gas exchange parameters (maximum photosynthesis rate $\left(\mathrm{A}_{\max }\right)$, transpiration rate $(\mathrm{E})$, stomatal conductance $\left(\mathrm{g}_{\mathrm{s}}\right)$ were measured using a LI6400 (Li-Cor Biosciences, Lincoln, Nebraska) at $25^{\circ} \mathrm{C}$, $1200 \mu \mathrm{mol}$ PAR m $\mathrm{m}^{-2} \mathrm{~s}^{-1}$ and $400 \mathrm{ppm} \mathrm{CO}_{2}$. Water use efficiency was calculated as $\mathrm{A}_{\max } / \mathrm{E}$ ratio. Measurements started on day 11 after the start of the drought treatment and were continued during the following 3 weeks. All measurements were determined on the second fully developed leaf in six replicates (two replicates per plot), twice a week (Monday and Thursday), between 8.30 and 12.00 am during the third cut in 2014 and 2015.

\section{Chlorophyll $a$ Fluorescence}

Maximum quantum efficiency of PSII $\left(F_{\mathrm{v}} / F_{\mathrm{m}}\right.$ ratio $)$ measurements started on day 8 after the start of the drought period and continued during the following 3 weeks. All measurements were done in fifteen replicates (five replicates per plot), twice a week (Thursday and Friday) during the third cut in 2014 and 2015, using a Pocket PEA ultra-portable chlorophyll fluorimeter (Hansatech Instruments, Norfolk, USA).

\section{Quality Parameters}

In both years, a sample of $1 \mathrm{~g}$ dried and ground leaf material collected at cut III was analysed in triplicate by Near Infra-Red Spectroscopy (NIRS) to quantify the water soluble carbohydrate content (WSC) according to the method of Wiseman et al. (1960), the organic matter digestibility (OMD) according to the method of De Boever et al. (1988), the crude protein content $(\mathrm{CP})$ and the neutral detergent fibre digestibility (NDFD). The NIRS calibration of the NDFD was based on in vitro digestibility (Goering and Van Soest 1970) and NDF (neutral detergent fibre), ADF (acid detergent fibre) analysis (Van Soest et al. 1991).

\section{Phytochemical Analysis}

Plant material was collected from the field experiment at cut III in 2014, lyophilised for 3 days, grounded in the grinder and kept in a dried and dark place for analysis of proline and phenolic compounds content. Proline was extracted from $100 \mathrm{mg}$ of lyophilised plant material with $50 \%$ (v/v) acetonitrile in three replicates. Extraction conditions, UPLC-PDAESI-MS/MS system setup and chromatographic conditions were according to Fariaszewska et al. (2016). The concentration of proline was expressed in $\mu \mathrm{g} \mathrm{g}^{-1}$ of dry plant material.

The concentration of flavonoids and phenolic acids was determined by the extraction of $100 \mathrm{mg}$ lyophilised plant material in three replicates using Thermo Scientific Dionex ASE 150 Accelerated Solvent Extractor. Extraction process and UPLC-PDA-ESI-MS/MS was based on methods described in detail by Fariaszewska et al. (2016). The content of flavonoids and phenolic acids was expressed in $\mu \mathrm{g} \mathrm{mg}^{-1}$ of dry plant material. The standards solution were obtained from Sigma-Aldrich (St Louis, MO, USA).

\section{Normalised Difference Vegetation Index (NDVI) Measurements}

The Normalised Differential Vegetation Index (NDVI) was calculated based on the crop reflection in the visual (VIS) and Near Infra-Red (NIR) range: NDVI $=(\mathrm{NIR}-\mathrm{VIS}) /$ (NIR + VIS), and has played an important role for satellitebased vegetation drought monitoring (Gu et al. 2007; Brown and de Beurs 2008). NDVI was measured in four technical replicates on each plot at the end of drought period (July 7 in 2014 and July 17 in 2015) using a handheld NDVI sensor (GreenSeeker, Trimble, Sunnyvale, CA, USA).

\section{Statistical Analysis}

The experiment was composed of nine varieties of grasses, two irrigation levels and three shelters (= replicates). Gas exchange and chlorophyll fluorescence parameters measurements were made per shelter during third regrowth, twice and five times, respectively. One biological and two technical samples were used for proline and phenolic compounds analysis for one shelter in the third regrowth. Quality parameters (NDF, AND, CP, WSC, OMD, NDFD) were analysed in one replicate per shelter. Dry matter yield and dry matter content were analysed in three replicates in five cuts in the first year and four cuts in the second year of field experiment. One-way and two-way ANOVA was used to analysis significant differences between varieties and irrigation levels. Tukey's test at a significance level of $\alpha=0.05$ was applied to determine the interaction between varieties and irrigation levels for all parameters and cuts using StatGraphic Centurion XVI. Simple Pearson's correlation among indices and 
yield in two water conditions and bi-plot graphs were performed by PQSTAT SOFTWARE 1.6.0 (PQStatSoftware, Poznań, Poland).

\section{Results}

\section{Soil Moisture Level}

Volumetric water content at $0-30 \mathrm{~cm}$ soil depth was maintained on average at $21.0-23.3 \%$ in 2014 and at $19.0-22.5 \%$ in 2015 for well-watered plants in cut III of the rain-out shelter experiment (Fig. 2). By the eighth day of the drought treatment, soil moisture level declined on average from 21.0 to $17.4 \%$ in 2014 and from 14.6 to $10.0 \%$ in 2015 . By the eleventh day it had declined on average to $15.0 \%$ in 2014 and $8.0 \%$ in 2015 of the experiment. At the 27 th day soil moisture level decreased on average to $9.0 \%$ in 2014 and $7.7 \%$ in 2015 .

\section{Dry Matter Yield}

Drought stress significantly decreased dry matter yield (DMY) in cut III in all tested varieties in 2014 and 2015. The reduction was lower in 2014 compared with 2015 (Table 1). Total dry matter yield slightly decreased in 2014 (on average by $4.3 \%$ ) and much more in 2015 (on average by $18.6 \%$ ). In the first year of experiment, the two varieties of L. multiflorum ('Melmia', 'Meldiva') had the highest total DMY in the control and drought conditions, respectively: 20.2 and 22.8 $\mathrm{t} \mathrm{ha}^{-1}$, while the $F$. pratensis varieties had the lowest total dry matter yield for irrigated and non-irrigated plots. Under drought stress conditions the highest reduction of total DMY in 2014 was found for 'Barolex' $(-10.1 \%)$, while 'Meltador' even showed a slight increase in total DMY $(+6.7 \%)$. 'Barolex' had the highest total DMY in the control conditions, while the lowest was found for 'Felopa' in 2015. After the drought period in cut III, 'Barolex' had the lowest reduction in total dry matter yield of $2015(-7.8 \%)$, while 'Merifest Tp.' had the highest reduction (-35.2\%).

Based on the STI both L. multiflorum varieties showed the highest tolerance to drought in 2014, the lowest tolerance was found for $F$. pratensis (Table 1). In 2015 however, analysis of total DMY and STI resulted in $F$. arundinacea as the most tolerant to drought, while $F$. pratensis and Festulolium were less tolerant.

\section{Dry Matter Content}

Under drought stress dry matter content significantly increased in cut III in the 2 years of the rain-out shelter experiment: with $44.0 \%$ on average in 2014 and $81.8 \%$ on average in 2015 (Table 2). The highest increase was observed in 'Felopa' (61.8\%) and the lowest in 'Meldiva' (33.5\%) in 2014. In contrast, the highest increase of dry matter content was found for 'Meltador' $(167.2 \%)$ and the lowest for both $F$. arundinacea varieties in 2015. In both regrowth periods, a significantly higher dry matter content remained for all varieties under drought conditions.

\section{Gas Exchange Parameters}

\section{Maximum Rate of Photosynthesis $\left(A_{\max }\right)$}

Maximum rate of photosynthesis $\left(\mathrm{A}_{\max }\right)$ values during the entire period of water deficit treatment are presented in Fig. 3. Drought stress reduced $\mathrm{CO}_{2}$ assimilation in 2014 with on average $29.2 \%$ and in 2015 with on average $28.4 \%$. The highest decrease was recorded in 'Merifest' (on average 37.5\%), 'Meldiva' (on average 35.4\%) in 2014 and in 'Meldiva' (on average $34.4 \%$ ) in 2015. The lowest decrease of photosynthesis intensity was found for 'Barolex' (on average 15.3\%) in 2014 and for 'Merifest' and 'Meltador' in 2015. The highest decrease of $\mathrm{CO}_{2}$ assimilation was determined at the 5th and 6th measurement for almost all varieties in both year of experiment, except 'Melmia' and 'Merifest', which characterised the highest decrease at the 4th and 2nd measurement, respectively.

\section{Transpiration Rate (E)}

All tested varieties reacted for drought stress by a decrease in transpiration: on average $58.2 \%$ in 2014 and $53.6 \%$ in 2015 compared to well-watered conditions (Fig. 4). The transpiration rate at the first measurement (11 days after the start of the drought) was clearly lower in 2015 compared with 2014. The highest reduction of this process was found for 'Melluck' (on average 67.4\%) in 2014 and for 'Felopa' (on average 59.5\%) in 2015.'Callina' had the lowest average decline of transpiration rate in 2014 and 'Merifest' and 'Merifest Tp' in 2015.

\section{WUE (Water Use Efficiency)}

Water use efficiency was quite different within the tested grass varieties. There was a higher increase of WUE in 2014 (on average by $77.8 \%$ ) compared with 2015 (on average by $65.7 \%$ ) under drought stress versus control treatment. The highest increase of WUE was found in 2014 for 'Melluck' in 2014 and 2015. In contrast, the lowest increase was recorded in 'Merifest' in both investigated years (Fig. 5).

\section{Stomatal Conductance $\left(\mathbf{g}_{\mathrm{s}}\right)$}

Stomatal conductance reduction in drought conditions was higher in 2015 on average $65.7 \%$ compared with $39.9 \%$ 


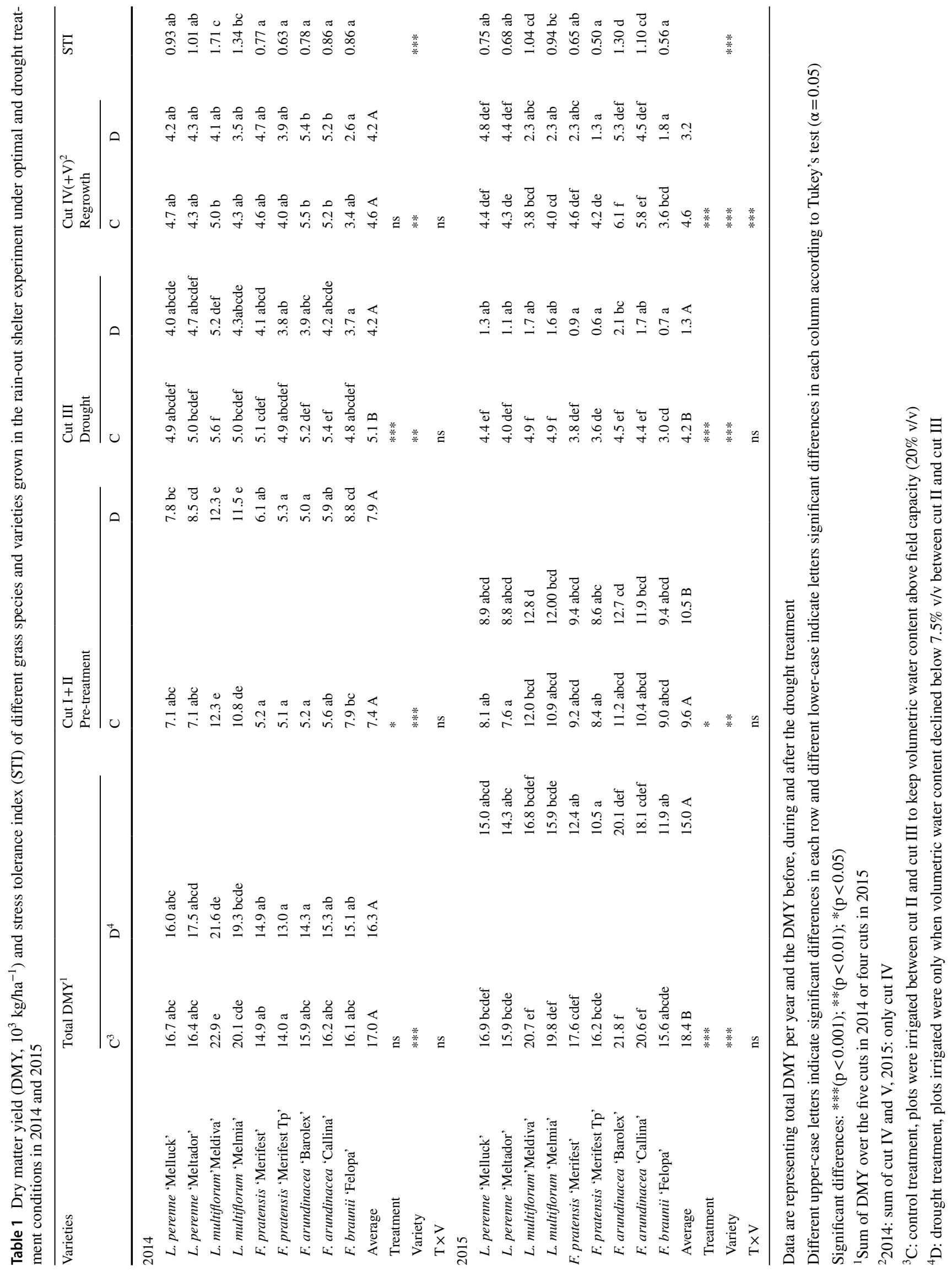




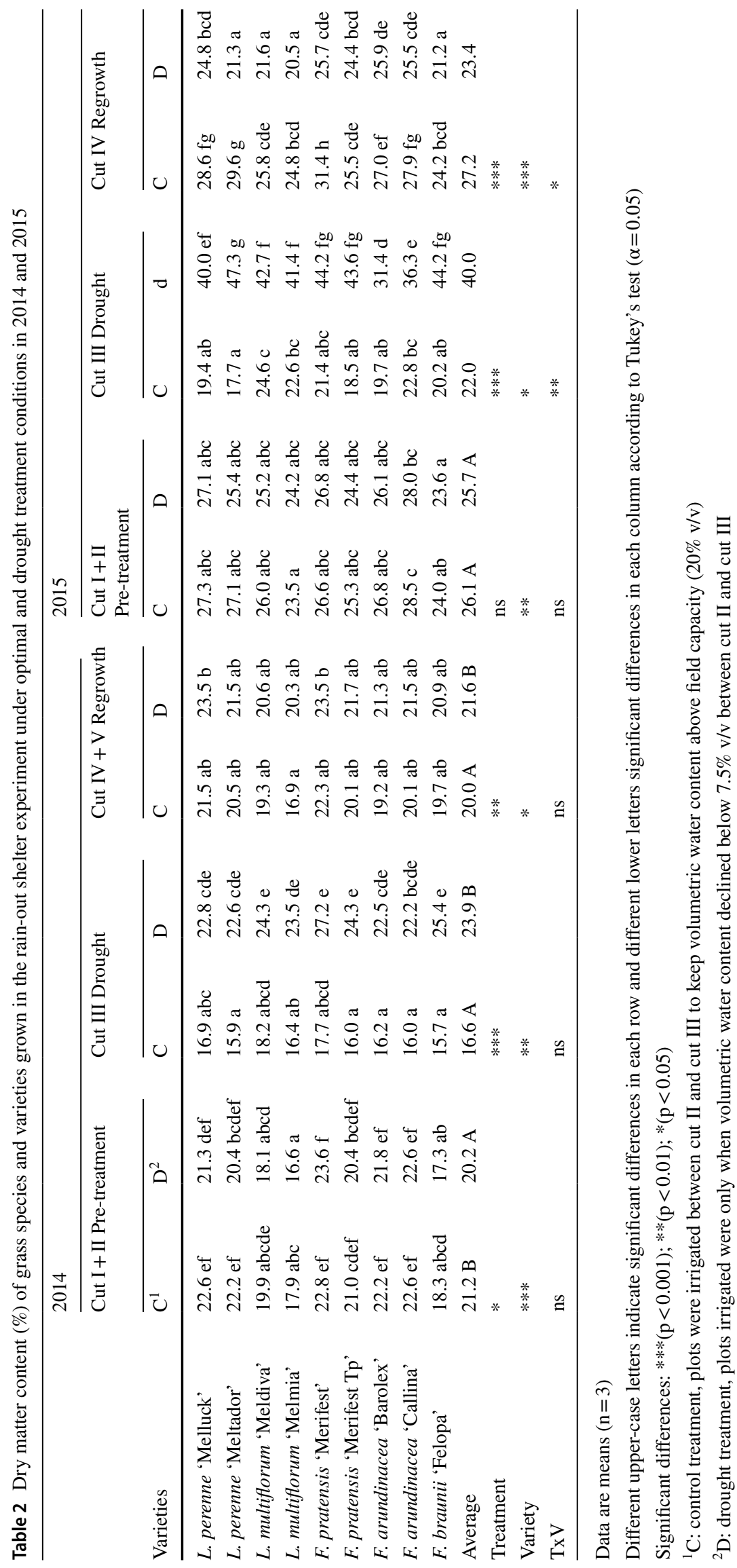




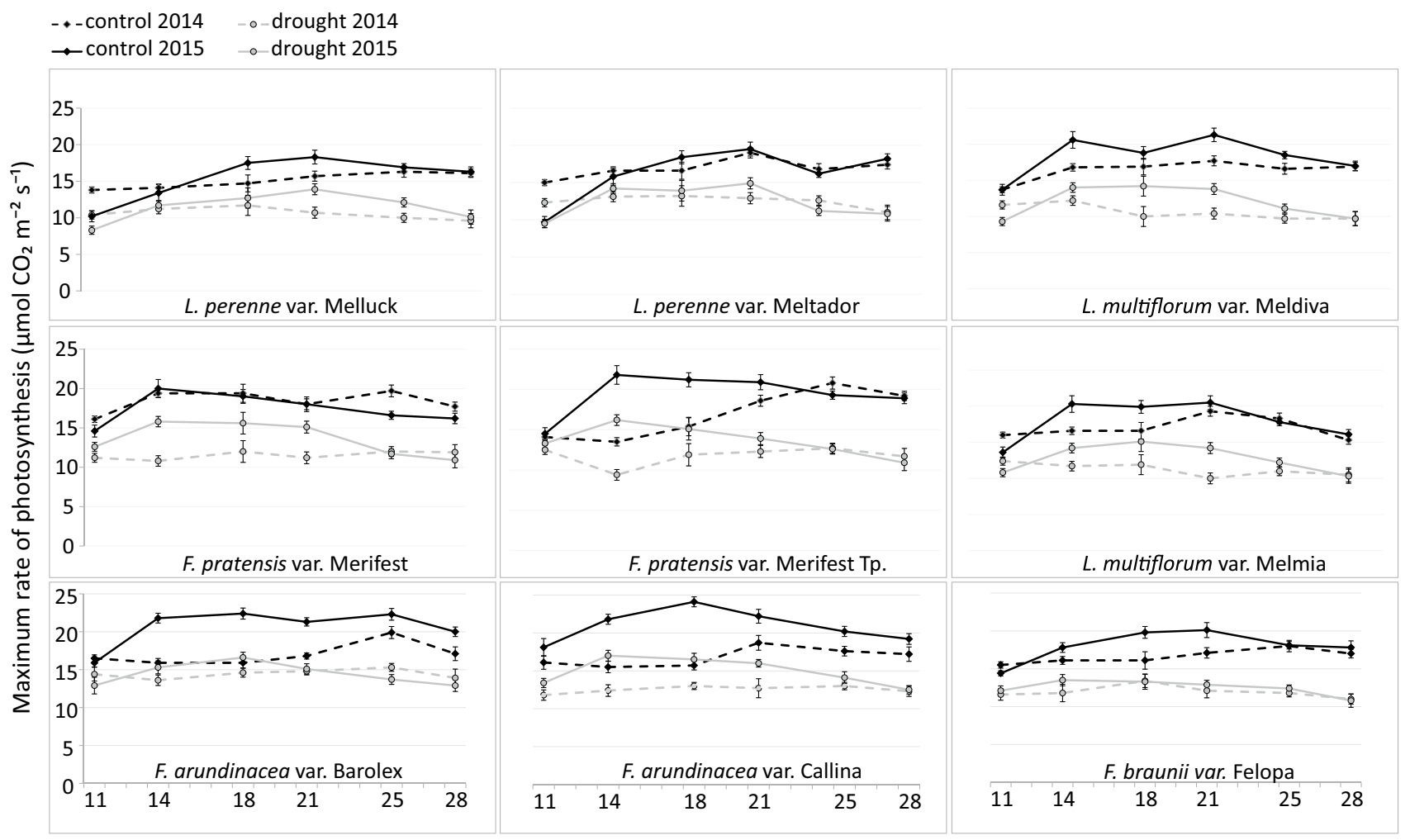

Days after start of drought treatment

Fig. 3 Maximum rate of photosynthesis $\left(\mathrm{A}_{\max }\right)$ of grass species and varieties grown in the field under optimal and drought treatment conditions in 2014 and 2015. Data are mean $\pm \operatorname{SE}(n=6)$

in 2014. The highest reduction of the stomatal conductance under drought stress was found for 'Felopa' (on average $48.2 \%$ ) in 2014 and for 'Melmia' (on average 48.1\%) in 2015. The lowest decrease in stomatal closure was recorded in 'Meldiva' (on average 28.0\%) in 2014 and 'Barolex'(on average 56.1\%) in 2015 (Fig. 6).

\section{Chlorophyll a Fluorescence}

\section{Quantum Efficiency Photosystem II $\left(F_{v} / F_{\mathrm{m}}\right.$ Ratio $)$}

Quantum efficiency of photosystem II decreased with progressive soil drying in both investigated years (Fig. 7). The average decrease amounted to $1.2 \%$ in 2014 year and $2.4 \%$ in 2015 year in all tested varieties (Fig. 7). The quantum efficiency of PSII dropped clearly at the sixth measurement for the varieties 'Meltador', 'Melmia' and 'Barolex' in 2014. A more gradual decrease was found for 'Melluck' and 'Merifest'. In 2015 the highest average decrease of $F_{v}$ ' $F_{\mathrm{m}}$ ratio was found in 'Melluck' (3.2\%). Almost all tested varieties had already higher difference between control and drought from the first measurement in 2015 compared to 2014 .

\section{Forage Quality Parameters}

The crude protein content decreased with $8.7 \%$ on average in 2014 in drought conditions, but increased with $20.3 \%$ on average in 2015 (Table 3). The highest reduction of crude protein was determined in L. multiflorum varieties in 2014. The highest increase of $\mathrm{CP}$ was found for both $F$. pratensis varieties and the lowest for 'Barolex'. Under drought stress conditions WSC content significantly increased with $30.9 \%$ on average in all tested varieties in 2014 and for almost varieties with $5.8 \%$ on average in 2015 . The highest increase of WSC content was found for both $F$. arundinacea varieties in 2014 and in 2015 for both $F$. pratensis varieties. Drought stress significantly decreased the acid detergent fibre (ADF) content with $9.4 \%$ on average in 2014 and with $15.1 \%$ on average in 2015 . The NDF content decreased also by $2.6 \%$ on average in 2014 and $3.4 \%$ in 2015. In the first year of the experiment the ADF decreased most in 'Merifest' and 'Felopa. However, decrease of the ADF content was highest in 'Meltador', 'Merifest' in 2015. The highest significant decrease under water deficit in NDF was determined in 'Meltador' in 2014 and in 'Merifest' in 2015. Water stress didn't significantly affect organic matter digestibility (OMD) in 2014, while a significant increase (by 3.7\%) 


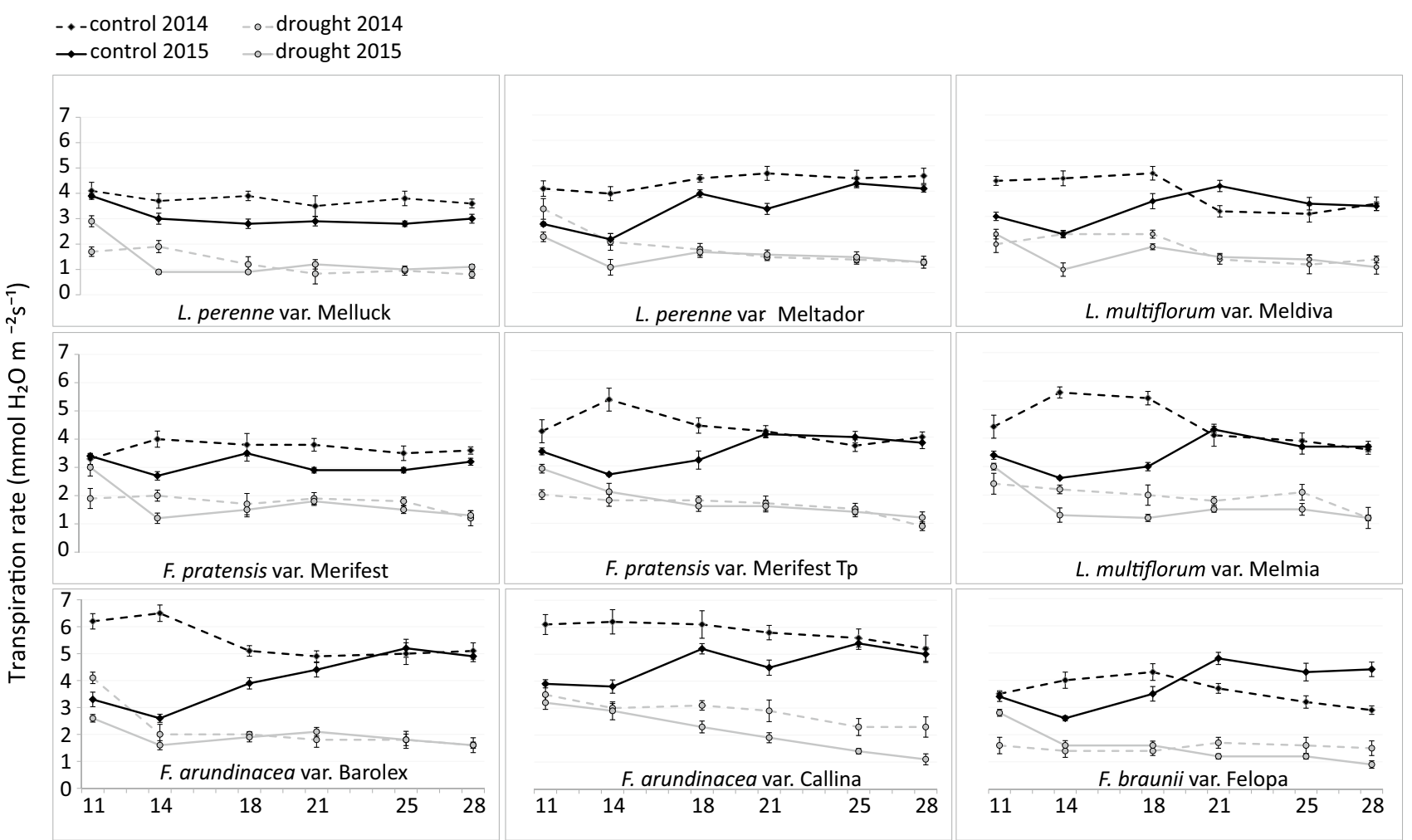

Days after start of drought treatment

Fig. 4 Transpiration rate (E) of grass species and varieties grown in the field under optimal and drought treatment conditions in 2014 and 2015. Data are mean \pm SE $(n=6)$

was determined in 2015. Under drought stress the highest increase of OMD was found for $F$. pratensis varieties, while 'Felopa' had a slight decrease (by 4.0\%). Over all, L. perenne and $F$. pratensis had the highest digestibility, while $L$. multiflorum varieties had the lowest digestibility, which is explained by the presence of stems at cut III. Under drought stress treatment NDFD significantly decreased with $3.1 \%$ on average in 2014 and with $1.7 \%$ on average in 2015 . The highest decrease in NDFD was determined in 'Melmia' in 2014 and in 'Felopa' in 2015.

\section{Proline and Phenolic Compounds Concentration}

The proline concentration significantly increased under drought treatment (on average 69.4\%) in all varieties (Table 4). The highest increase of proline content was found for 'Merifest Tp' $(229.1 \%)$ and the lowest for 'Melmia' (36.9\%) under drought stress. 'Felopa' accumulated $960 \mu \mathrm{g} \mathrm{g}^{-1}$ of proline under water deficit. In contrast, in the drought stress treatment the lowest concentration of this osmolite was determined in 'Callina' and 'Barolex'. The concentration of flavonoids significantly increased under drought stress (by average 37.9\%) in all varieties (Table 4). The highest increase of flavonoids concentration had both varieties of Italian ryegrass, $66.5 \%$ for 'Meldiva' and $66.0 \%$ for 'Melmia'. In contrast, the lowest increase was found for 'Felopa' and 'Meltador': 18.0 and 18.7\%, respectively. Water deficit caused a significant increase in the concentration of phenolic acids in all varieties (by average 19.1\%). The highest increase of this compounds was found for 'Felopa' (38.0\%) and 'Meldiva' (34.5\%).

\section{Normalised Difference Vegetation Index (NDVI) Measurements}

Overall, NDVI of the drought treatment plots was significantly smaller than in the control conditions in 2014 and 2015, but a higher decrease was observed in 2015 (on average by $13.8 \%$ ) than in 2014 (on average by $2.5 \%$ ) (Table 5) The highest values of NDVI were found for 'Melluck' under control conditions in both investigated years, while the lowest were observed in 'Melmia' in 2014 and 'Felopa' in 2015 under drought stress conditions. Moreover, F. arundinacea varieties showed no decrease in NDVI in drought stress conditions in 2014 and only a low decrease in 2015 . 


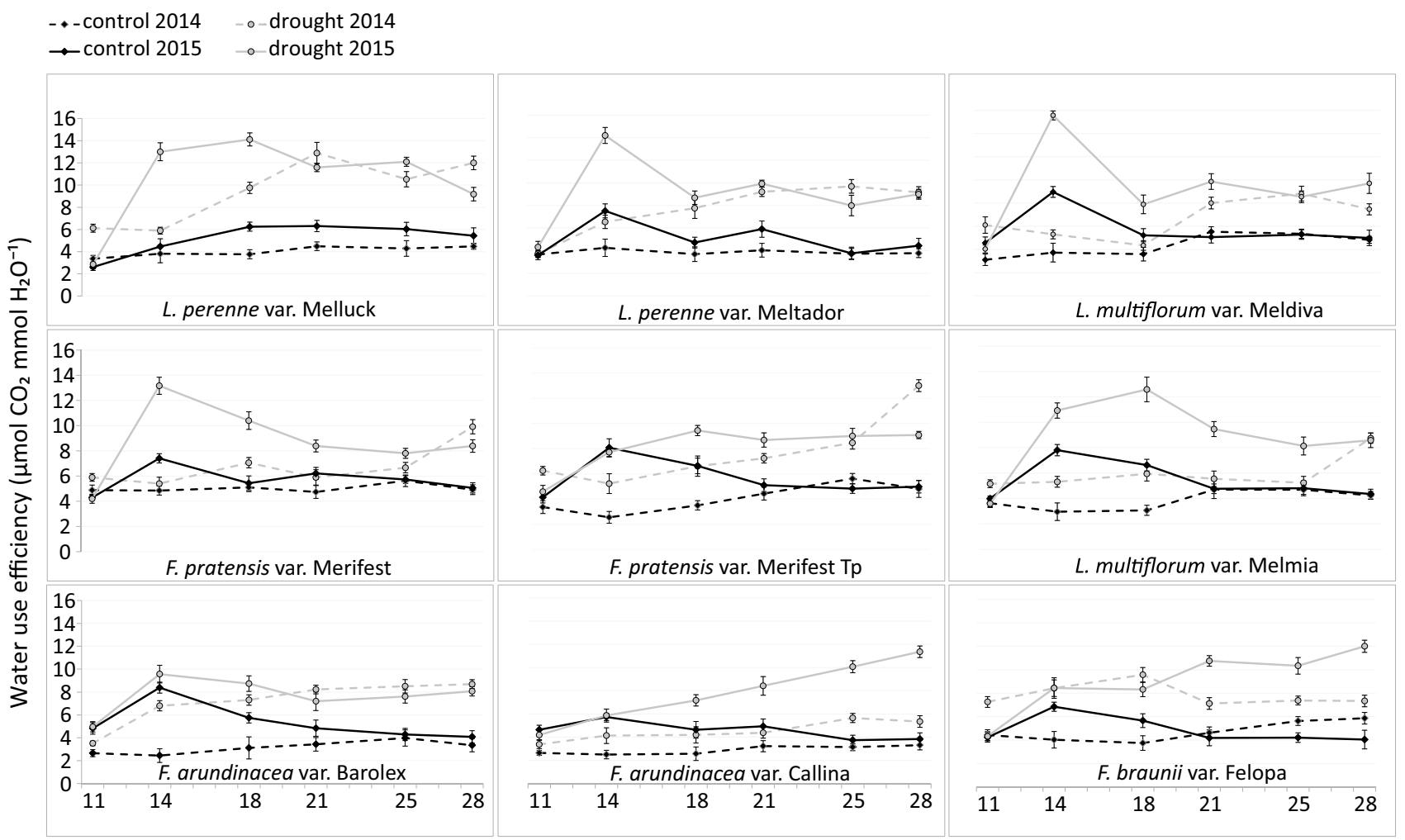

Days after start of drought treatment

Fig. 5 Water use efficiency of grass species and varieties grown in the field under optimal and drought treatment conditions in 2014 and 2015. Data are mean $\pm S E(n=6)$

\section{Principal Components and Correlation Analysis}

Principal component analysis (PCA) revealed that two dimensions explained $66.8 \%$ and $84.1 \%$ of total variation in drought stress in 2014 and 2015, respectively (Fig. 8). Two main clusters were separated by dimension 1: on the left side the control treatment and on the right side the drought treatment. Dimension 1 had a high positive correlation with DMY, ADF, NDF, $F_{v} / F_{\mathrm{m}}$ ratio and all gas exchange parameters and a negative correlation with DMC, WUE and WSC in both years, while dimension 2 had a high positive correlation with OMD and NDFD in both years. Dimension 2 was negatively correlated with PA and Fl in 2014. Bi-plot graphs showed that $F$. braunii 'Felopa' was similar in reaction as $F$. pratensis and L. perenne in both investigated years under control and drought stress conditions. L. multiflorum and $F$. arundinacea varieties clearly clustered as separate groups under drought and control conditions in 2014 and 2015. The main driver for L. multiflorum was its low OMD (and associated parameters) in both years and its high DMY in 2014. The main driver for $F$. arundinacea was its high DMY (and associated photosynthesis parameters), especially in 2015.

Table 6 shows that the accumulation of phenolic acids had a positive and significant correlation with DMY in control and drought stress treatment in 2014. DMC was significantly negatively correlated with DMY and STI under drought treatment in 2015. The transpiration rate and stomatal conductance were clearly associated in the drought treatment of both years and even in the control treatment of 2015 (Table 6).

\section{Discussion}

Many authors confirmed that mild drought stress causes changes in productivity, physiological processes and chemical composition of crop plants (Mafakheri et al. 2010; Ball 2001; AbdElgawad et al. 2015). Our results showed a significant reduction of dry matter yield in Festuca, Lolium and Festulolium in the field experiment, confirming the results of other authors in many grass species like F. arundinacea, Poa pratensis, Phleum pratense, Phalaris canariensis (Kallida et al. 2008; Turner et al. 2012). In our studies the drought treatment reduced dry matter yield more in 2015 than in 2014. L. multiflorum had the highest dry matter production in drought and control conditions in 2014, while $F$. arundinacea had the highest dry matter production in both conditions in 2015. Moreover, F. pratensis and F. arundinacea 


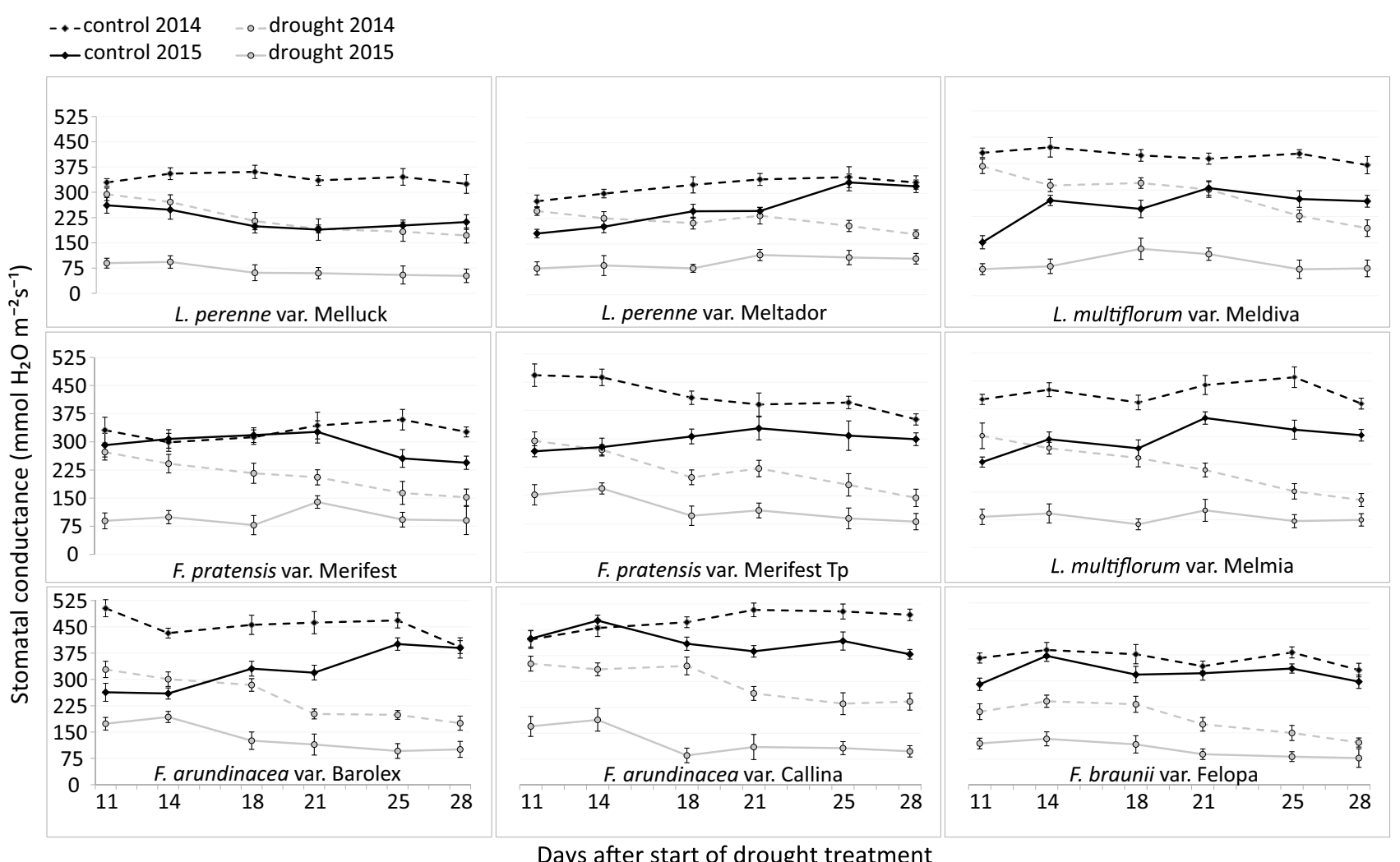

Fig. 6 Stomatal conductance $\left(\mathrm{g}_{\mathrm{s}}\right)$ of grass species and varieties grown in the field under optimal and drought treatment conditions in 2014 and 2015. Data are mean $\pm \operatorname{SE}(n=6)$

showed a higher production in optimal water conditions in 2015 compared with 2014, which may be related to a deeper and better developed root system in the second year (Deru et al. 2012; Cougnon et al. 2017). All tetraploids varieties had a tendency for a lower dry matter production under control and drought stress conditions, except for L. perenne, where a slightly better total dry matter yield was found in the tetraploid variety, but only in the first year after sowing under drought conditions. The order of drought tolerance based on the total DMY and STI under drought stress was $\mathrm{Lm}>\mathrm{Lp}>\mathrm{Fa}>$ Felo $>\mathrm{Fp}$ in 2014. A first reason for the differences between 2014 and 2015 was the lower precipitation in May and June in 2015. This resulted in a low soil moisture level before the start of the drought period under the rainout shelter in 2015. Reduction of dry matter yield could also be related to development of the sward and age of the plants, confirming the results of Staniak (2013). Younger grasses better withstand water deficit in the soil and they didn't have a destroyed sward through a previous stress factor (here the same drought plots of 2014 received a drought treatment in 2015). F. arundinacea as a tolerant species had the highest dry matter production and the lowest reduction in drought stress conditions from all tested varieties and species in 2015. In contrast, drought treatment during 3 weeks in the pot experiment had the highest impact on DMY of $F$. arundinacea compared to other tested species of grasses (Fariaszewska et al. 2016), which could be due to a underdeveloped root system. Generally, the order in drought tolerance based of total DMY and STI of different species under drought stress was following: $\mathrm{Fa}>\mathrm{Lm}>\mathrm{Lp}>$ Felo $>\mathrm{Fp}$ in 2015. Moreover, a high STI index is considered as higher yield in stress and non-stress conditions. Under irrigation and subtropical field conditions Neal et al. (2009) noted that $F$. arundinacea had a higher production of dry matter yield than L. perenne. Results of Ebrahimiyan et al. (2012) confirmed this trend and showed a lower reduction of DMY and better production of $F$. arundinacea in the second year of control and drought treatment. Jeronimo et al. (2014) showed a significant dry matter yield reduction in L. perenne (by 16\%) and F. pratensis (by 12\%) during drought conditions in the case of a grazing exploitation.

Many researchers proved that photosynthesis decreases under drought stress as an effect of stomata closure (leading to a lower $\mathrm{CO}_{2}$ availability), damaged photosynthetic apparatus including PSI and PSII, intensified photo-inhibition, changes in photosynthetic pigments or damage to chloroplast biochemistry under stress factors (Fu and Huang 2001; Flexas and Medrano 2002; Kong et al. 2015). Reduction of 


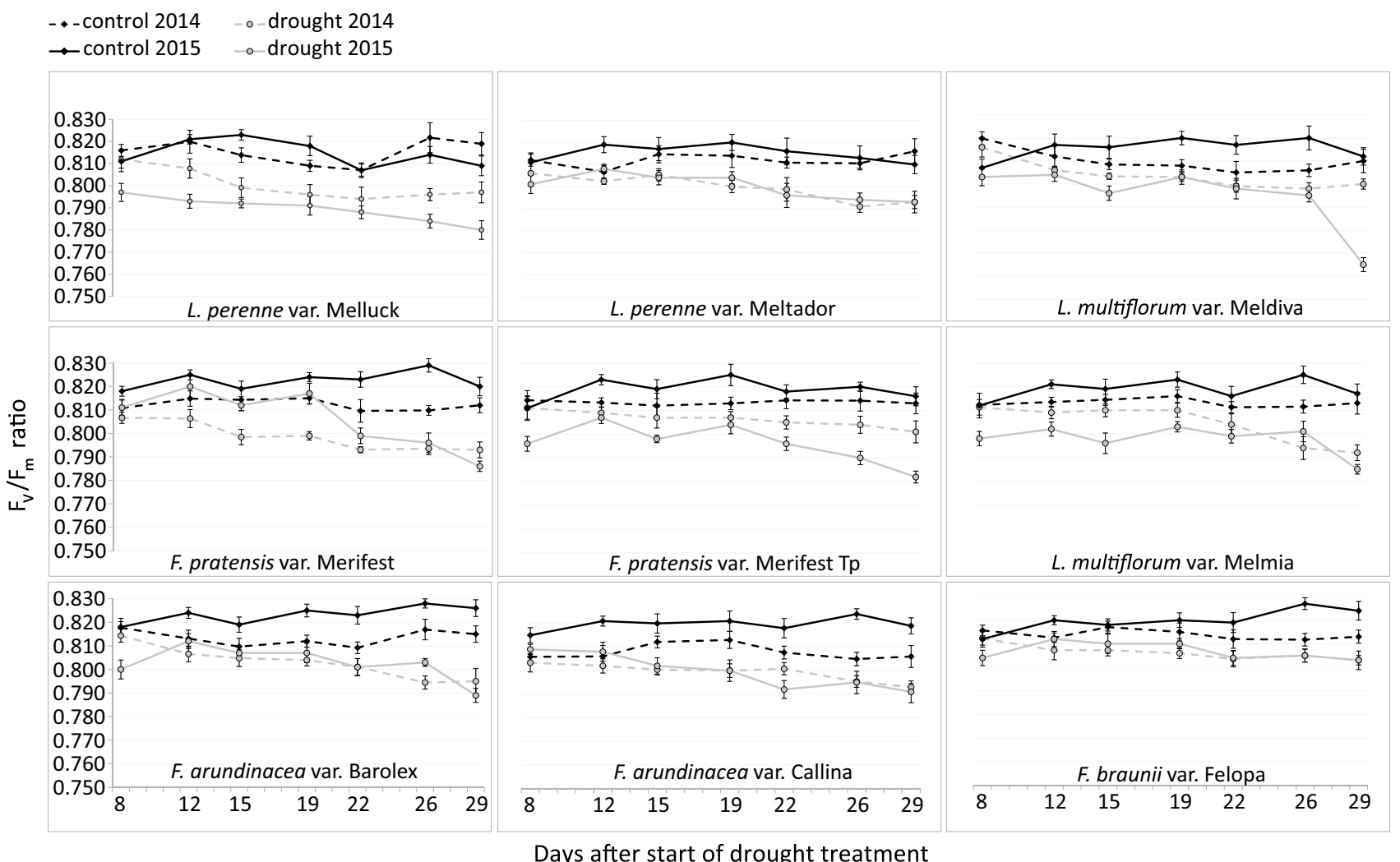

Fig. $7 F_{\mathrm{v}} / F_{\mathrm{m}}$ ratio of grass species and varieties grown in the field under optimal and drought treatment conditions in 2014 and 2015 . Data are mean $\pm \operatorname{SE}(n=15)$

photosynthesis rate was similar in 2014 and 2015 and the highest reduction of this process was found for L. multiflorum in both years and for $F$. pratensis in 2014. The previous pot experiment of Fariaszewska et al. (2016) showed that intensity of photosynthesis decreased the most in $F$. pratensis. Under drought stress conditions plants loss turgor pressure. The plant reacts through closing the stoma, in order to reduce the transpiration rate and to keep more water into the cells. Festuca species and F. braunii had a higher reduction of stomatal conductance in 2014. In 2015, both stomatal conductance and transpiration rate were similar for all species. Significant reduction of transpiration rate due to drought in forage grasses ( F. arundinaea, L. perenne, $D$. glomerata, $L$. chineses) and $T$. aestivum varieties were found in many studies: Huang and Gao (1999), Xu and Zhou (2005), Olszewska et al. (2010), Staniak (2013), and Guan et al. (2015). Changes in the intensity of physiological processes under drought stress conditions can also be the result of the repair mechanisms, e.g. induction of LEA protein, lipid transfer protein, protease inhibitors (Starck 2002) or they are associated with a decrease in the export of assimilates from the leaf blade to other plant organs (Stark 1995). Water use efficiency (WUE) is often regarded as an indicator of yield under drought stress and even an element of plant drought resistance. Under drought treatment, WUE increased in all varieties more in 2014 (average by 78\%) than 2015 (on average by 66\%).It could be related to a better developed root system, a higher reduction of the transpiration process or a more efficient use of a finite water supply in 2015 compared to 2014. In general, L. perenne had high values of WUE in 2014 and Lolium species and $F$. braunii in 2015 in drought stress conditions. Transpiration rate and WUE had a significant negative correlation coefficient in optimal and drought stress conditions (Fig. 8 and Table 6) Rumasz-Rudnicka (2010) and Fariaszewska et al. (2016) confirmed this negative correlation between WUE and transpiration in different forage grasses and the increase of WUE during lack of watering in the pot experiments. In recent years, the measurements of chlorophyll fluorescence makes it possible to evaluate of the health and functionality of the photosynthetic apparatus during the process of $\mathrm{CO}_{2}$ assimilation under environmental stresses (Strasser et al. 2000; Sayed 2003; Clark et al. (2000). In general, our results did not show clear differences between the tested species and varieties. Nevertheless, the $F_{V} / F_{\mathrm{m}}$ decreased more in 2015 than in 2014. A clear decrease of $F_{v} / F_{m}$ ratio was observed after 2 weeks of drought treatment in most of tested varieties in 2014 and at the 8th day of the drought treatment in 2015. 


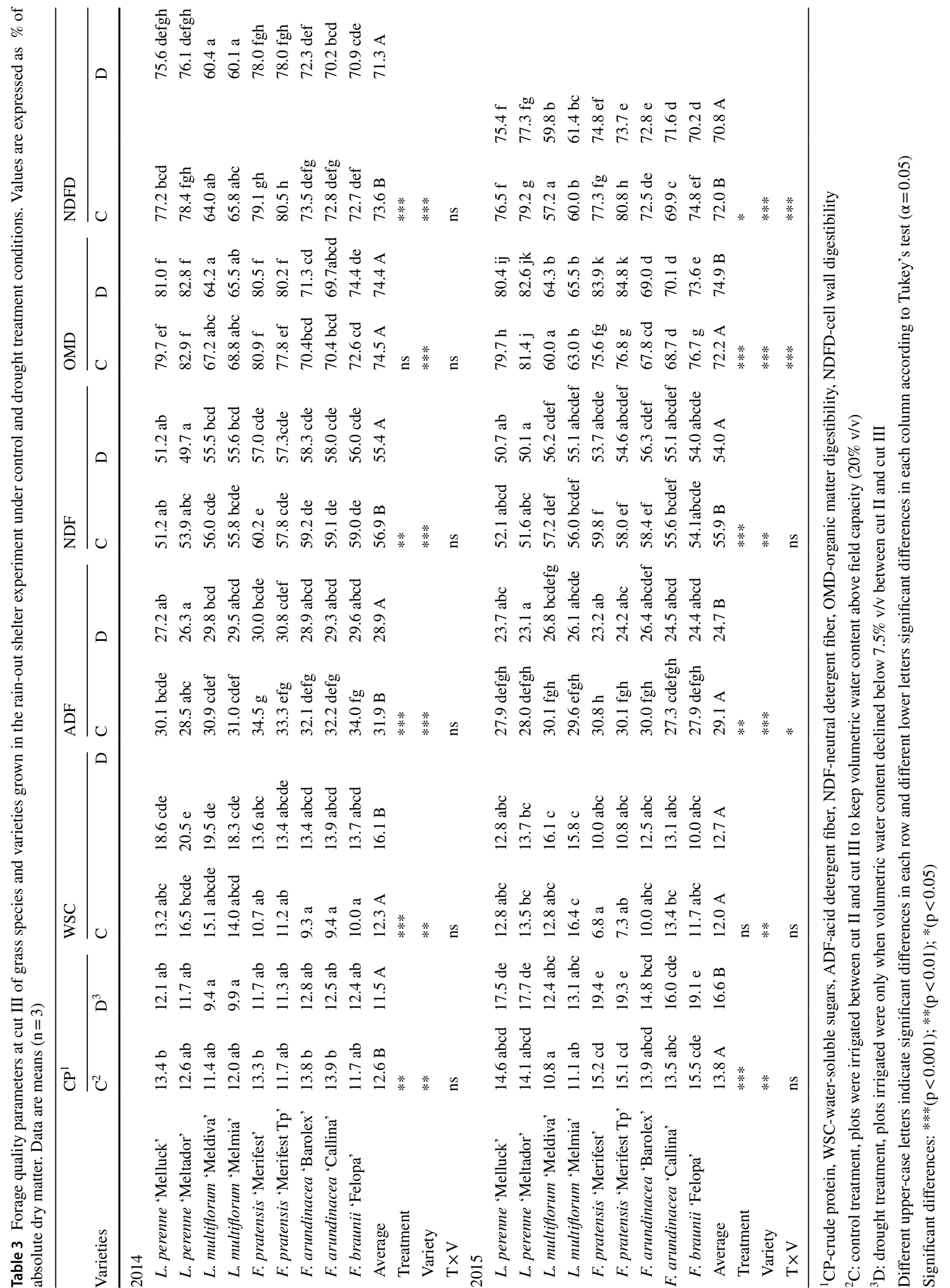


Table 4 Concentration of proline, flavonoids and phenolic acids at cut III of grass species and varieties under optimal and drought treatment conditions in 2014

\begin{tabular}{|c|c|c|c|c|c|c|}
\hline \multirow[t]{2}{*}{ Varieties } & \multicolumn{2}{|c|}{ Proline $\left(\mu \mathrm{g} \mathrm{g}^{-1}\right)$} & \multicolumn{3}{|c|}{ Flavonoids $\left(\mu \mathrm{g} \mathrm{mg}^{-1}\right)$} & \multirow{2}{*}{$\begin{array}{l}\text { Phenolic } \\
\text { acid } \\
\left(\mu \mathrm{gg}^{-1}\right) \\
\text { D }\end{array}$} \\
\hline & $\mathrm{C}^{1}$ & $\mathrm{D}^{2}$ & $\mathrm{C}$ & $\mathrm{D}$ & $\mathrm{C}$ & \\
\hline L. perenne 'Melluck' & $369.4 \mathrm{de}$ & $666.9 \mathrm{~h}$ & $24.6 \mathrm{hi}$ & 35.31 & $34.5 \mathrm{e}$ & $40.4 \mathrm{~h}$ \\
\hline L. perenne 'Meltador' & $195.6 \mathrm{ab}$ & $563.9 \mathrm{gh}$ & $15.5 \mathrm{~cd}$ & $18.4 \mathrm{ef}$ & $37.6 \mathrm{fg}$ & $41.8 \mathrm{ij}$ \\
\hline L. multiflorum 'Meldiva' & $343.6 \mathrm{~cd}$ & 470.4 efg & 23.3 ghi & $38.8 \mathrm{~m}$ & $41.5 \mathrm{hi}$ & $55.8 \mathrm{~m}$ \\
\hline L. multiflorum 'Melmia' & $378.6 \mathrm{de}$ & 391.9 def & $14.4 \mathrm{bc}$ & 23.9 ghi & $38.0 \mathrm{~g}$ & $49.1 \mathrm{k}$ \\
\hline F. pratensis 'Merifest' & $302.8 \mathrm{bcd}$ & 466.9 efg & $20.3 \mathrm{f}$ & $26.8 \mathrm{j}$ & $38.5 \mathrm{~g}$ & $43.0 \mathrm{j}$ \\
\hline F. pratensis 'Merifest Tp' & $151.4 \mathrm{a}$ & $498.2 \mathrm{fg}$ & 18.4 ef & $22.5 \mathrm{~g}$ & $26.6 \mathrm{c}$ & $30.5 \mathrm{~d}$ \\
\hline F. arundinacea 'Barolex' & $167.4 \mathrm{a}$ & $232.6 \mathrm{abc}$ & $17.3 \mathrm{de}$ & $22.6 \mathrm{gh}$ & $29.5 \mathrm{~d}$ & $34.0 \mathrm{e}$ \\
\hline F. arundinacea 'Callina' & $141.7 \mathrm{a}$ & $206.2 \mathrm{ab}$ & $24.7 \mathrm{i}$ & $32.9 \mathrm{k}$ & 52.01 & $58.3 \mathrm{~m}$ \\
\hline F. braunii 'Felopa' & $580.0 \mathrm{gh}$ & $960.6 \mathrm{i}$ & $12.2 \mathrm{a}$ & $14.4 \mathrm{bc}$ & $12.9 \mathrm{a}$ & $17.8 \mathrm{~b}$ \\
\hline Average & $292.3 \mathrm{~A}$ & $495.3 \mathrm{~B}$ & $19.0 \mathrm{~A}$ & $26.2 \mathrm{~B}$ & $34.6 \mathrm{~A}$ & $41.2 \mathrm{~B}$ \\
\hline Treatment & $* * *$ & & $* * *$ & & $* * *$ & \\
\hline Variety & $* * *$ & & $* * *$ & & $* * *$ & \\
\hline TxV & $* * *$ & & $* * *$ & & $* * *$ & \\
\hline
\end{tabular}

${ }^{1} \mathrm{C}$ : control treatment, plots were irrigated between cut II and cut III to keep volumetric water content above field capacity $(20 \% \mathrm{v} / \mathrm{v})$

${ }^{2} \mathrm{D}$ : drought treatment, plots irrigated were only when volumetric water content declined below $7.5 \% \mathrm{v} / \mathrm{v}$ between cut II and cut III

Different upper-case letters indicate significant differences in each row and different lower letters significant differences in each column according to Tukey's test $(\alpha=0.05)$

Significant differences: $* * *(\mathrm{p}<0.001) ; * *(\mathrm{p}<0.01) ; *(\mathrm{p}<0.05)$
Table 5 Normalized Differential Vegetation Index (NDVI) of the different grass species and varieties grown in the rain-out shelter experiment under optimal and drought treatment conditions in 2014 and 2015

\begin{tabular}{lllllll}
\hline Varieties & \multicolumn{2}{l}{2014} & & & 2015 \\
\cline { 2 - 3 } \cline { 5 - 6 } & $\mathrm{C}$ & $\mathrm{D}$ & & $\mathrm{C}$ & $\mathrm{D}$ \\
\hline L. perenne 'Melluck' & $0.894 \mathrm{a}$ & $0.856 \mathrm{ab}$ & & $0.896 \mathrm{a}$ & $0.829 \mathrm{ab}$ \\
L. perenne 'Meltador' & $0.886 \mathrm{a}$ & $0.852 \mathrm{ab}$ & $0.872 \mathrm{bc}$ & $0.795 \mathrm{ab}$ \\
L. multiflorum'Meldiva' & $0.848 \mathrm{ab}$ & $0.835 \mathrm{ab}$ & $0.849 \mathrm{~cd}$ & $0.724 \mathrm{ab}$ \\
L. multiflorum 'Melmia' & $0.866 \mathrm{ab}$ & $0.822 \mathrm{~b}$ & & $0.854 \mathrm{~cd}$ & $0.751 \mathrm{ab}$ \\
F. pratensis 'Merifest' & $0.875 \mathrm{ab}$ & $0.858 \mathrm{ab}$ & $0.888 \mathrm{ab}$ & $0.697 \mathrm{ab}$ \\
F. pratensis 'Merifest Tp' & $0.881 \mathrm{ab}$ & $0.862 \mathrm{ab}$ & $0.878 \mathrm{ab}$ & $0.674 \mathrm{ab}$ \\
F. arundinacea 'Barolex' & $0.856 \mathrm{ab}$ & $0.875 \mathrm{a}$ & & $0.879 \mathrm{ab}$ & $0.847 \mathrm{a}$ \\
F. arundinacea 'Callina' & $0.839 \mathrm{~b}$ & $0.839 \mathrm{ab}$ & & $0.848 \mathrm{~d}$ & $0.810 \mathrm{ab}$ \\
F. braunii 'Felopa' & $0.884 \mathrm{ab}$ & $0.833 \mathrm{ab}$ & & $0.852 \mathrm{~cd}$ & $0.601 \mathrm{~b}$ \\
Average & $0.870 \mathrm{~B}$ & $0.848 \mathrm{~A}$ & & $0.868 \mathrm{~B}$ & $0.748 \mathrm{~A}$ \\
Treatment & $* * *$ & & $* * *$ & \\
Variety & $* * *$ & & $* *$ & \\
TxV & $*$ & & $*$ & \\
\hline
\end{tabular}

Different letters indicate significant differences within the columns $(\mathrm{p}<0.05)$

Significant differences: $* * *(\mathrm{p}<0.001) ; * *(\mathrm{p}<0.01) ; *(\mathrm{p}<0.05)$
Huang and Gao (1999) showed a significant reduction of $F_{\sqrt{ }}$ $F_{\mathrm{m}}$ ratio after 3 weeks of stop irrigation (RWC $40 \%$ ) in $F$. arundinacea varieties (on average by $3.7 \%$ ) with variation between varieties.

The length of the growing season may also affect water availability and grasses ability to maintain forage quality under drought stress. As is known, forage quality decrease with plant age, maturity stage at harvest and environmental conditions, because leaf/steam ratio decreases (Nelson 1994; Peterson et al. 1992; Buxton 1995). In drought stress conditions ADF and NDF decreased in all tested grasses in both years of our field experiment. Our study showed the highest decrease of ADF in F. pratensis and NDF in L. perenne in both years. Reduction of NDF and ADF content was found also by Staniak (2013) and Küchenmeister et al. (2013) in $F$. braunii, L. perenne, L. multiflorum, F. pratensis and $T$. repens under water deficit. High temperature may increase lignin accumulation and decrease quality, but drought stress may actually increase forage quality by delaying maturity which explains much of the improved digestibility (Buxton 1995; Cherney and Hall 2008). Our study showed a significant increase of organic matter digestibility in 2015.

The crude protein content $(\mathrm{CP})$ increased during the drought period of 2015 and this was in accordance with other studies with F. pratensis, $P$. pratense, $F$. pratensis, $L$. perenne, L. multiflorum and F. braunii (Madziar and Latanowicz 1996; Olszewska 2009; Trzaskoś et al. 2001; Staniak 


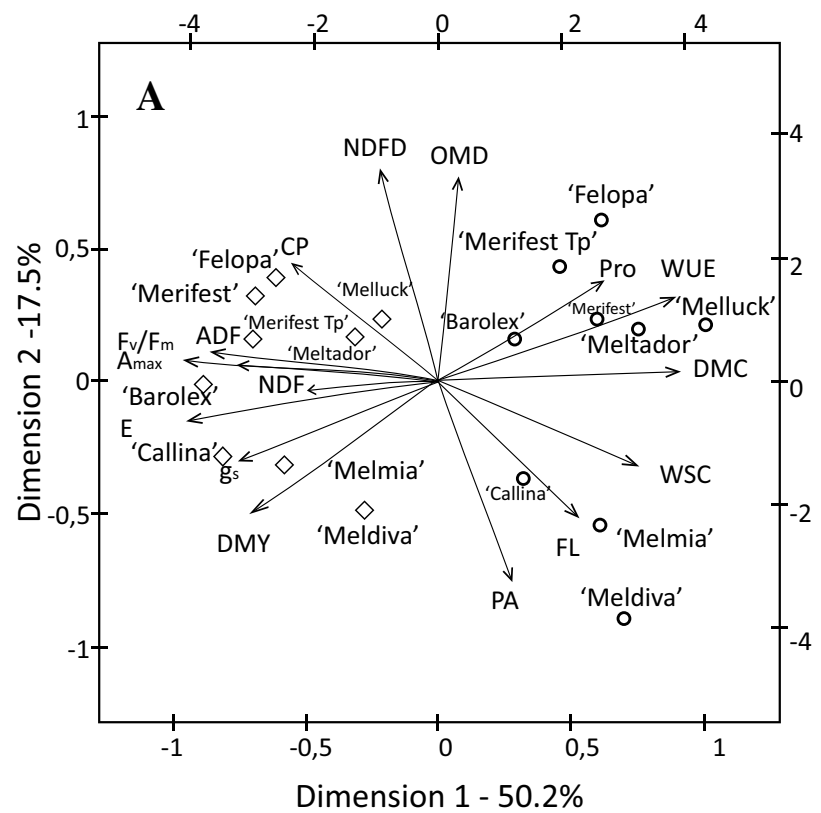

o drought treatment

$\diamond$ control treatment

Fig. 8 The bi-plot display of dry matter yield, physiological attributes and forage quality parameters of grass varieties under control and drought treatment conditions in 2014 (a) and 2015 (b). DMY dry matter yield, $D M C$ dry matter content, $A_{\max }$ maximum rate of photosynthesis, $E$ transpiration rate, $g_{s}$ stomatal conductance, $F v / F m$

2013). Increase of CP, might be explained by delayed maturity and changes in the leaf/stem ratio (Peterson et al. 1992). Moreover, if both nitrogen and water are present in the same soil horizon, they may be taken up together and forage CP concentration may be unaffected or may be increased if soil nitrogen is more available than water (Buxton 1995).

Under drought stress conditions a significant increase of WSC was found only in 2014. In addition, Festuca species had a higher increase of WSC than Lolium species, mainly F. arundinacea in 2014 and $F$. pratensis in 2015. Kozłowski and Kukułka (1996), Thomas and James (1999), and Küchenmeister et al. (2013) confirmed the increase of WSC concentration in L. perenne under drought stress. Moreover Kozłowski and Goliński (1996) signalised an increase of WSC in F. pratensis and Turner et al. (2012) in $F$. arundinacea under drought conditions. Similar relationships were demonstrated by Staniak (2013), in the second year of vegetation: under water deficit in the soil: $F$. pratensis accumulated more WSC compared to well-watered conditions, while L. multiflorum and F. braunii decreased the accumulation of sugars. The accumulation of WSC has been often associated with an increase in drought tolerance and survival of grasses (Volaire and Thomas 1995; Volaire and Leliévre 1998). According to many studies, increase of sugars content may change the osmotic potential, which is a physiological

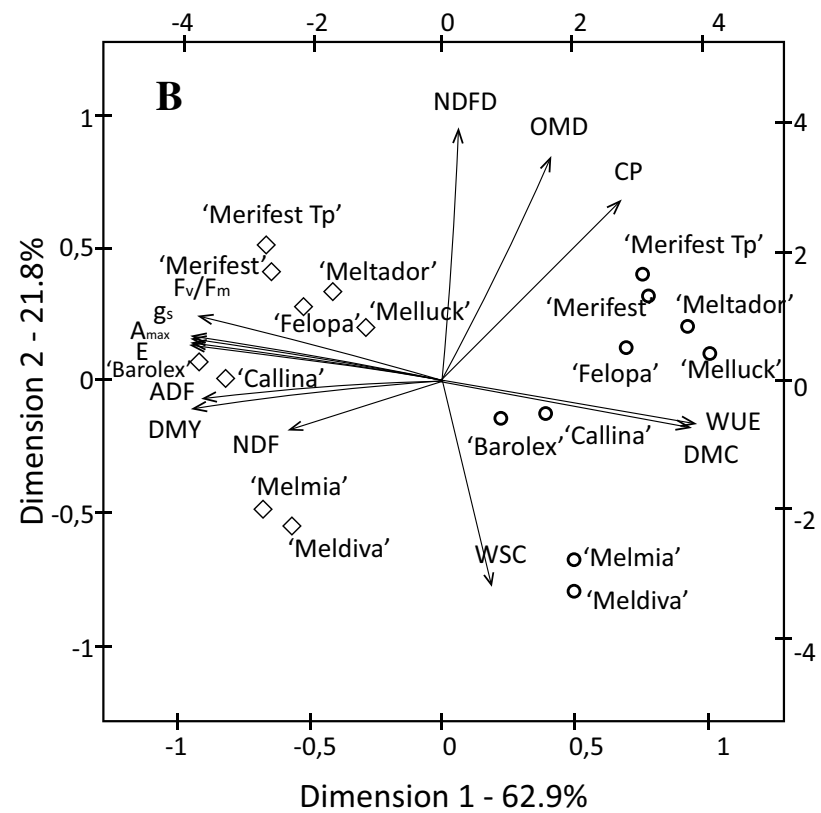

ratio-maximum quantum efficiency of PSII, Pro proline content, $\mathrm{Fl}$ flavonoids content, $P A$ phenolic acid content, $C P$ crude protein, WSC water-soluble sugars, $A D F$ acid detergent fiber, $N D F$ neutral detergent fiber, $O M D$ organic matter digestibility, $N D F D$ cell wall digestibility

mechanism in responses to drought (Morgan 1984; DaCosta and Huang 2006). Additionally, the reserve of sugars could be utilised as the primary source for continued biomass production following drought stress (Chaves 1991).

Our results showed that proline concentration increased in all grass species and varieties in response to drought. According to Bandurska and Jóźwiak (2010) accumulation of proline depends on many factors such as plant's age, which may explain a higher concentration of proline in $L$. perenne and F. braunii in 2014. F. pratensis and L. perenne were characterised by the highest increase of this osmolite. Proline seems to be associated with a better drought tolerance in Festuca compared with Lolium species, which was also suggested by Perlikowski et al. (2014) and Fariaszewska et al. (2016).

Phenolic compounds such as phenolic acids and flavonoids have regulative and anti-oxidative proprieties and it is believed that they can be an important element to responses to environmental stresses (Weidner et al. 2007; Rosicka-Kaczmarek 2004). The synthesis and behaviour of phenolic compounds such as flavonoids and phenolic acids during abiotic stress is still not well-documented in forage grasses and other crops. The phenolic compounds have a benzene ring and are therefore very reactive structures. The benzene ring as a $\pi$-electron system can neutralize UV 
Table 6 Correlation coefficient of different traits under optimal (below diagonal) and drought treatment (above diagonal) conditions during cut III in 2014 and 2015

\begin{tabular}{|c|c|c|c|c|c|c|c|c|c|c|c|}
\hline Trait & DMY & $\mathrm{A}_{\max }$ & $\mathrm{E}$ & WUE & $\mathrm{g}_{\mathrm{s}}$ & $F_{\mathrm{v}} / F_{\mathrm{m}}$ & DMC & STI & Pro & $\mathrm{Fl}$ & PA \\
\hline \multicolumn{12}{|l|}{2014} \\
\hline DMY & & 0.31 & 0.07 & -0.24 & $0.53^{*}$ & -0.27 & -0.17 & $0.97^{* * *}$ & -0.21 & $0.49^{*}$ & $0.68^{*}$ \\
\hline $\mathrm{A}_{\max }$ & 0.11 & & $0.58^{*}$ & -0.22 & 0.10 & -0.05 & -0.36 & -0.24 & -0.42 & $-0.48^{*}$ & -0.25 \\
\hline $\mathrm{E}$ & 0.41 & 0.09 & & $-0.87^{* *}$ & $0.65^{*}$ & -0.29 & -0.41 & 0.22 & $-0.77^{*}$ & 0.08 & 0.50 \\
\hline WUE & -0.32 & 0.24 & $-0.94^{* * *}$ & & $-0.60^{*}$ & 0.16 & -0.09 & -0.39 & $0.66^{*}$ & -0.16 & $-0.62^{*}$ \\
\hline $\mathrm{g}_{\mathrm{s}}$ & 0.22 & -0.06 & -0.15 & 0.08 & & -0.25 & -0.46 & $0.67^{* *}$ & $-0.68^{*}$ & $0.71^{*}$ & $0.74^{* *}$ \\
\hline$F_{\mathrm{v}} / F_{\mathrm{m}}$ & $-0.81^{* * *}$ & -0.29 & -0.53 & 0.38 & -0.04 & & 0.13 & -0.26 & 0.34 & -0.37 & -0.54 \\
\hline DMC & $0.55^{*}$ & 0.09 & -0.42 & 0.46 & 0.34 & -0.19 & & -0.17 & 0.41 & -0.17 & -0.30 \\
\hline STI & $0.84^{* * * *}$ & -0.01 & 0.08 & -0.09 & 0.32 & $-0.65^{*}$ & $0.58^{*}$ & & -0.35 & 0.56 & $0.76^{* *}$ \\
\hline Pro & -0.32 & -0.23 & $-0.70^{* * *}$ & $0.65^{*}$ & -0.13 & -0.19 & 0.13 & -0.17 & & -0.39 & $-0.66^{*}$ \\
\hline $\mathrm{Fl}$ & $0.54^{*}$ & -0.31 & 0.17 & -0.23 & 0.14 & -0.45 & $0.54^{*}$ & 0.37 & 0.54 & & $0.75^{* *}$ \\
\hline $\mathrm{PA}$ & $0.71^{* *}$ & 0.01 & 0.46 & -0.43 & 0.24 & $-0.75^{*}$ & 0.38 & $0.65^{*}$ & 0.38 & 0.67 & \\
\hline \multicolumn{12}{|l|}{2015} \\
\hline DMY & & 0.09 & 0.32 & $-0.52^{*}$ & 0.49 & -0.20 & $-0.78^{* * *}$ & $0.99^{* * *}$ & & & \\
\hline $\mathrm{A}_{\max }$ & 0.12 & & $0.51^{*}$ & $-0.60^{* *}$ & $0.56^{*}$ & 0.39 & -0.02 & 0.02 & & & \\
\hline E & -0.01 & $0.83^{* * *}$ & & $-0.91^{*}$ & $0.86^{* * *}$ & 0.38 & $-0.60^{* *}$ & 0.26 & & & \\
\hline WUE & 0.30 & -0.17 & $-0.68^{* *}$ & & $-0.92^{* * *}$ & $-0.52^{*}$ & 0.44 & -0.21 & & & \\
\hline $\mathrm{g}_{\mathrm{s}}$ & -0.10 & $0.84^{* * *}$ & $0.92^{* * *}$ & -0.55 & & 0.49 & $-0.52^{*}$ & 0.17 & & & \\
\hline$F_{\mathrm{v}} / F_{\mathrm{m}}$ & -0.19 & $0.61^{* *}$ & 0.39 & -0.12 & $0.62^{*}$ & & 0.04 & -0.27 & & & \\
\hline DMC & $0.56^{*}$ & 0.29 & 0.15 & 0.23 & 0.24 & 0.11 & & $-0.71^{* *}$ & & & \\
\hline STI & $0.89^{* * * *}$ & 0.42 & 0.33 & 0.11 & 0.17 & 0.03 & $0.53^{*}$ & & & & \\
\hline
\end{tabular}

$D M Y$ dry matter yield, $A_{\max }$ maximum rate of photosynthesis, $E$ transpiration rate, $g_{s}$ stomatal conductance, $F_{\sqrt{ }} / F_{m}$ ratio maximum quantum efficiency of PSII, DMC-dry matter content, STI stress tolerance index, Pro proline content, $F l$ flavonoids content, $P A$ phenolic acid content Significant correlation: $* * *(\mathrm{p}<0.001) ; * *(\mathrm{p}<0.01) ; *(\mathrm{p}<0.05)$

and visible radiation (Bilger et al. 2001). Lolium species had a higher increase of these compounds than Festuca species, but the highest increase of phenolic acids was presented in F. braunii. Hura et al. (2007) and Sullivan and Teramura (1990) suggested that the protection of the photosynthetic apparatus during drought stress may additionally depend on the high concentration of phenolic compounds in the leaf tissue. Moreover, many authors confirmed the accumulation of phenolic compounds as an effect of water deficit: e.g. in spring Triticosecale, $M$. sativa, T. aestivum and Festuca, Lolium, Festulolium species (Hura et al. 2008; Kang et al. 2011; Gregorová et al. 2015; Fariaszewska et al. 2016) and it may be closely related to drought tolerance. Correlation analysis demonstrated that intensity of photosynthesis had a significant negative correlation with flavonoids, suggesting that the up-regulation of the shikimic acid pathway involved in production of secondary metabolites was under down-regulated photosynthesis (Jaafar et al. 2008). The synthesis of the basic skeleton of secondary metabolites is dependent on the carbon assimilated during photosynthesis (Asada 1994). The increase in production of secondary metabolites under low photosynthesis might be due to increased shikimic acid pathway activity under stressed conditions, especially under water deficit and low photosynthesis (Jaafar et al. 2012).

NDVI, which is the normalised difference between a visible red reflectance and near infrared (NIR), has played an important role for satellite-based vegetation drought monitoring $(\mathrm{Gu}$ et al. 2007; Brown and de Beurs 2008). In our studies, the retention of the NDVI, exhibited the fluctuation of soil moisture and stress in tested forage grasses under drought stress (Table 5). Our results showed a relationship among NDVI and drought conditions, which confirms the results of $\mathrm{Gu}$ et al. (2007) and Gu et al. (2008) who estimated drought in grasslands in central United States. Generally, high NDVI values reflect greater vigour and photosynthesis process of vegetation canopy (Gao 1996). This was confirmed by our results especially in F. arundinacea varieties, which had a high photosynthesis and NDVI values under drought stress conditions in both years of the experiment. 


\section{Conclusions}

Mild drought stress has a significant impact on the production and quality of forage grasses, hence breeding of more drought tolerant species and varieties of forage grasses is key in adaptation to future drought periods. Physiological parameters show that plants react within 2 weeks after the start of the drought stress. In general, the physiological parameters show that photosynthesis is reduced and this results clearly in a decreased dry matter yield due to drought. This is also true for the accumulation of biochemical parameters. However, the correlations between dry matter yield and the examined parameters are not always clear and straightforward. Also, the differential growth reaction of the different grass species towards drought is not clearly linked to a specific parameter or process. The rain-out shelter experiment confirms the results of the previously reported pot experiment (Fariaszewska et al. 2016) that $L$. multiflorum is less impacted by a drought period especially in the first mowing year after establishment. In contrast, the drought tolerance reaction of $F$. arundinacea in the second mowing year was not picked up by the pot experiment. This can be mainly attributed to root growth (in deeper soil layers), that could not be assessed in the pot experiment.

Funding This work was supported by the European Union's Seventh Framework Programme, project PROFICIENCY (Contract 245751).

Open Access This article is licensed under a Creative Commons Attribution 4.0 International License, which permits use, sharing, adaptation, distribution and reproduction in any medium or format, as long as you give appropriate credit to the original author(s) and the source, provide a link to the Creative Commons licence, and indicate if changes were made. The images or other third party material in this article are included in the article's Creative Commons licence, unless indicated otherwise in a credit line to the material. If material is not included in the article's Creative Commons licence and your intended use is not permitted by statutory regulation or exceeds the permitted use, you will need to obtain permission directly from the copyright holder. To view a copy of this licence, visit http://creativecommons.org/licenses/by/4.0/.

\section{References}

Abbasi, A. R., Sarvestani, R., Mohammadi, B., \& Baghery, A. (2014). Drought stress-induced changes at physiological and biochemical levels in some common vetch (Vicia sativa L.) genotypes. Journal of Agriculture, Science and Technology, 16, 505-5016.

AbdElgawad, H., Farfan-Vignolo, E. R., De Vos, D., \& Asard, H. (2015). Elevated $\mathrm{CO}_{2}$ mitigates drought and temperature-induced oxidative stress differently in grasses and legumes. Plant Science, $231,1-10$

Asada, K. (1994). Production and action of active oxygen species in photosynthetic tissues. In: Foyer, C.H., Mullineaux, P.M. (eds)
Causes of photooxidative stress and amelioration of defense system in plants. CRS Press: Boca Raton, pp. 77-103.

Bahrani, M. J., Bahrami, H., \& Haghighi, A. A. K. (2010). Effect of water stress on ten forage grasses native or introduced to Iran. Grassland Science, 56, 1-5.

Ball, D. M., Collins, M., Lacefield, G. D., Martin, N.P., Mertens, D. A., Olson, K. E., Putnam, D. H., Undersander, D. J., Wolf, M.W. (2001). Understanding Forage Quality. In American Forage and Grasslands Council, the National Forage Testing Association and the National Hay Association. pp. 1-17.

Bandurska, H., \& Jóźwiak, W. (2010). A comparison of the effects of drought on proline accumulation and peroxidases activity in leaves of Festuca rubra L. and Lolium perenne L. Acta Societatis Botanicorum Poloniae, 79, 111-116.

Bates, L. S., Waldren, R. P., \& Teare, I. D. (1973). Rapid determination of free proline for water -stress studies. Plant and Soil, 39, 205-207.

Bilger, W., Johnsen, T., \& Schreiber, U. (2001). UV-excited chlorophyll fluorescence as a tool for the assessment of UV-protection by the epidermis of plants. Journal of Experimental Botany, 52, 2007-2014.

Bray, E. A. (1993). Molecular responses to water deficit. Plant Physiology, 103, 1035-1040.

Bray, E. A. (1997). Plant responses to water deficit. Trends in Plant Science, 2, 48-54.

Brown, M. E., \& de Beurs, K. M. (2008). Evaluation of multi-sensor semi-arid crop season parameters based on NDVI and rainfall. Remote Sensing of Environment, 112, 2261-2271.

Buxton, D. R. (1995). Growing quality forages under variable environmental conditions. Western Canadian Dairy Seminar: ForagesThe Foundation of Your Feeding Program. University of Alberta, Department of Agricultural, Food and Nutritional Science. http:// www.wcds.ca/proc/1995/wcd95123.htm.

Chaves, M. M. (1991). Effect on water deficit on carbon assimilation. Journal of Experimental Botany, 42, 1-16.

Cherney, J. H., \& Hall, M. H. (2008). Forage quality in perspectives. Agronomy facts (pp. 1-4). PA, USA: The Pennsylvania State University.

Clark, A. J., Landolt, W., Bucher, J. B., \& Strasser, R. J. (2000). Beech (Fagus sylvatica) response to ozone exposure assessed with a chlorophyll fluorescence performance index. Environmental Pollution, 109, 501-507.

Cornic, G. (1994). Drought stress and high light effects on leaf photosynthesis. In N. R. Baker \& J. R. Boyer (Eds.), Photoinhibition of photosynthesis from molecular mechanisms to the field (pp. 297-313). Oxford: Bios Scientific Publishers.

Cougnon, M., De Swaef, T., Lootens, P., Baert, J., De Frenne, P., Shahidi, R., et al. (2017). In situ quantification of forage grass root biomass, distribution and diameter classes under two $\mathrm{N}$ fertilisation rates. Plant and Soil, 411, 409-422.

DaCosta, M., \& Huang, B. (2006). Osmotic adjustment associated with variation in bentgrass tolerance to drought stress. Journal of the American Society for Horticultural Science, 131, 338-344.

De Boever, J., Cottyn, B. G., Buysse, F. X., \& Vanacker, J. M. (1988). The use of cellulase technique to predict digestibility, metabolizable and net energy of forages. Animal Feed Science and Technology, 19, 247-260.

Deru, J., Van Eekeren, N., De Boer, H. (2012). Rooting density of three grass species and eight Lolium perenne cultivars. In 24th EGF General Meeting on "Grassland-a European Resource?" Grassland Science in Europe (eds.) Goliński P., M. Warda and P. Stypiński., vol. 17, pp. 604-606.

Ebrahimiyan, M., Majidi, M., \& Mirlohi, A. (2012). Genotypic variation and selection of traits related to forage yield in tall fescue under irrigated and drought stress environments. Grass and Forage Sci., 68, 59-71. 
Fariaszewska, A., Aper, J., Van Huylenbroeck, J., Baert, J., De Riek, J., Staniak, M., et al. (2016). Mild drought stress-induced changes in yield, physiological processes and chemical composition in Festuca, Lolium and Festulolium. Journal of Agricultural and Crop Research, 203, 103-116.

Fernandez, G.C.J. (1992). Effective selection criteria for assessing plant stress tolerance. In: Proceedings of the international symposium on adaptation of vegetables and other food crops in temperature and water stress, Taiwan 13-16 August, pp. 257-270

Flexas, J., \& Medrano, H. (2002). Drought-inhibition of photosynthesis in C-3 plants: Stomatal and nonstomatal limitation revisited. Annals of Botany, 89, 183-189.

Fu, J., \& Huang, B. (2001). Involvement of antioxidants and lipid peroxidation in the adaptation of two cool-season grasses to localized drought stress. Environmental and Experimental Botany, 45, 105-114.

Gao, B.-C. (1996). NDWI-a normalized difference water index for remote sensing of vegetation liquid water from space. Proceedings of SPIE the International Society for Optical Engineering, 58(3), 257-266.

Goering, H. K., Van Soest, P. J., (1970). Forage fibre analysis (Apparatus, Reagents, Procedures and Some Application) Agricultural Handbook No. 379, U.S. Department of Agriculture.

Gregorová, Z., Kováčik, J., Klejdus, B., Maglovski, M., Kuna, R., Hauptvogel, P., et al. (2015). Drought-induced responses of physiology, metabolites, and proteins in Triticum aestivum. Journal of Agriculture and Food Chemistry, 63, 8125-8133.

Gu, J., Brown, J. F., Verdin, J. P., \& Wardlof, B. (2007). A five-year analysis of MODIS NDVI and NDWI for grassland drought assessment over the central Great Plains of the United States. Geophysical Research Letters. https://doi.org/10.1029/2006G L029127.

Gu, J., Hunt, E., Wardlow, B., Basara, J. B., Brown, J. F., \& Verdin, J. P. (2008). Evaluation of MODIS NDVI and NDWI for vegetation drought monitoring using Oklahoma Mesonet soil moisture data. Geophysical Research Letters. https://doi. org/10.1029/2008GL035772.

Guan, X.-K., Song, L., Wang, T.-C., Turner, N. C., \& Li, F. M. (2015). Effect of drought on the gas exchange, chlorophyll fluorescence and yield of six different-era spring wheat cultivars. Journal of Agronomy and Crop Science, 201, 253-266.

He, J. X., Wang, J., \& Liang, H. G. (1995). Effect of water stress on photochemical function and protein metabolism of photosystem II in wheat leaves. Physiologia Plantarum, 93, 771-777.

Huang, B., \& Gao, H. (1999). Physiological responses of diverse tall fescue cultivars to drought stress. Horticultural Science, 34, 897-901

Hura, T., Hura, K., \& Grzesiak, M. (2008). Contents of total phenolics and ferulic Acid, and PAA activity during water potential changes in leaves of maize single-cross hybrids of different drought tolerance. Journal of Agronomy and Crop Science, 194, 104-112.

Hura, T., Hura, K., Grzesiak, M., \& Rzepka, A. (2007). Effect of long-term drought stress on leaf gas exchange and fluorescence parameters in C3 and C4 plants. Acta Physiologiae Plantarum, 29, 103-113.

Jaafar, H. Z. E., Ibrahim, M. H., \& Karimi, E. (2012). Phenolics and flavonoids compounds, phenylanine ammonia lyase and antioxidant activity responses to elevated $\mathrm{CO}_{2}$ in Labisia pumila (Myrisinaceae). Molecules, 17, 6331-6347.

Jaafar, H. Z. E., Mohamed, H. N. B., \& Rahmat, A. (2008). Accumulation and partitioning of total phenols in two varieties of Labisia pumila Benth under manipulation of greenhouse irradiance. Acta Horticulturae, 797, 387-392.

Jeronimo, P. A., Hrabě, F., Knot, P., \& Kvasnovsky, M. (2014). Evaluation of suitability of grass species for dry conditions (water stress).
Acta Universitatis Agriculturae et Silviculturae Mendelianae Brunensis, 62, 953-960.

Kallida, R., Faiz, A. C., \& Shaimi, N. (2008). Water stress effects on perennial grasses growth and behavior. Options Mediterraneennes Series A., 79, 303-313.

Kang, Y., Han, Y., Torres-Jerez, I., Wang, M., Tang, Y., \& Monteros, M. (2011). System responses to long-term drought and re-watering of two contrasting alfalfa varieties. The Plant Journal, 68 , 871-889.

Kikuzaki, H., Hisamoto, M., Hirose, K., Akiyama, K., \& Taniguchi, H. (2002). Antioxidants properties of ferulic acid and its related compounds. Journal of Agriculture and Food Chemistry, 50, 2161-2168.

Kong, H., Palta, J. A., Siddiqu, K. H. M., Stefanova, K., Xiong, Y. C., \& Turner, N. C. (2015). Photosynthesis is reduced, and seeds fail to set and fill at similar soil water contents in grass pea (Lathyrus sativus L.) subjected to terminal drought. Journal of Agronomy and Crop Science, 201, 241-252.

Kozłowski, S., \& Goliński, P. (1996). The effect of site conditions on the occurence of carbohydrates in cultivars of Festuca pratensis L. Prace Kom. Nauk Rol Kom Nauk Leśn PTPN, 81, 92-102.

Kozłowski, S., \& Kukułka, I. (1996). Lifespan of Polish cultivars of Lolium perenne. PTPN, Wydz. Nauk Rol. Leś. Prace Kom. Nauk Rol Kom Nauk Leśn, 81, 114-120.

Küchenmeister, K., Küchenmeister, F., Kayser, M., Wrange-Monning, N., \& Isselstein, J. (2013). Influence of drought stress on nutritive value of perennial forage legumes. International Journal of Plant Production, 7, 693-710.

Lawlor, D. E. (2002). Limitation to photosynthesis in water-stressed leaves: stomata vs. metabolism and the role of ATP. Annals of Botany, 89, 871-885.

Lu, C., \& Zhang, J. (1999). Effect of water stress of photosynthesis, chlorophyll fluorescence and photo inhibition in wheat plants. Australian Journal of Plant Physiology, 25, 883-892.

Madziar, Z., \& Latanowicz, M. (1996). The productivity and nutrient content in crops of selected forage grass species in pot combination under different soil moisture conditions. PTPN, Wydz. Nauk Rol. Leś. Prace Kom. Nauk Rol Kom Nauk Leśn, 8, 129-135.

Mafakheri, A., Siosemardeh, A., Bahramnejad, B., Struik, P. C., \& Sohrabi, Y. (2010). Effect of drought stress on yield, proline and chlorophyll contents in three chickpea cultivars. Australian Journal of Crop Science, 8, 580-585.

Morgan, J. M. (1984). Osmoregulation and water stress in higher plants. Annual Review of Plant Biology, 35, 299-319.

Nakabayashi, R., Mori, T., \& Saito, K. (2014). Alternation of flavonoid accumulation under drought stress in Arabidopsis thaliana. Plant Signaling \& Behavior. https://doi.org/10.4161/psb.29518.

Neal, J. S., Fulkerson, W. J., Lawrie, R., \& Barchia, M. (2009). Difference in yield and persistence among perennial forages used by the dairy industry under optimum and deficit irrigation. Crop Pasture Science, 60, 1071-1087.

Nelson, D. J., Moser. L. E. (1994). Plant factors affecting forage quality. In: forage quality. evaluation and utilization. In G. C.Fahey, M. Collins, D. R. Martens, R.E. Moser. (eds.) American Society of Agronomy, Madison, pp. 115-154.

Olszewska, M. (2009). Response of cultivars of meadow fescue (Festuca pratensis HUDS) and timothy (Phleum pratense L.) grown on organic soil to moisture deficiency. Acta Scientiarum Polonorum seria Agricultura, 8, 37-46.

Olszewska, M., Grzegorczyk, S., Olszewski, J., \& Bałuch-Małecka, A. (2010). A comparison of the response of selected grass species to water stress. Grassland Science, 1, 9-26.

Perlikowski, D., Kosmala, A., Rapacz, M., Kościelniak, J., Pawłowicz, I., \& Zwierzykowski, Z. (2014). Influence of short-term drought conditions and subsequent re-watering on the physiology and proteome of Lolium multiflorum/Festuca arundinacea introgression 
forms, with contrasting levels of tolerance to long-term drought. Plant Biology, 16, 385-394.

Peterson, P. R., Sheaffer, C. C., \& Hall, M. H. (1992). Drought effects on perennial forage legume yield and quality. Agronomy Journal, 84, 774-779.

Rosicka-Kaczmarek, J. (2004). Polyphenols as natural food antioxidants. Przeglad Piekarski i Cukierniczy, 6, 12-16.

Rumasz-Rudnicka, E. (2010). Influence of irrigation and nitrogen fertilizer an assimilation and transpiration of westerwolds ryegrass. Acta Agrophysica, 15, 395-408.

Sairam, R. K., Veerbhadra, K. R., \& Srivastava, G. C. (2002). Differential response of wheat genotypes to long term salinity stress in relation to oxidative stress, antioxidant activity and osmolyte concentration. Plant Science, 163, 1037-1046.

Sayed, O. H. (2003). Chlorophyll fluorescence as a tool in cereal crop research. Photosynthetica, 41, 321-330.

Staniak, M. 2013: Response of selected species and cultivars of forage grass to water shortage in the soil. Monogr. Rozpr. Nauk. IUNGPIB, Puławy, Poland, pp. 217

Starck, A. (2002). Integration mechanisms of photosynthesis and biomass distribution in adverse environmental conditions. Zeszyty Problemowe Postępów Nauk Rolniczych, 481, 203-212.

Stark, Z. (1995). Correlation between photosynthesis and distribution of assimilates and the tolerance of plants for unfavorable environment conditions. Post epy Nauk Rol, 3, 19-35.

Strasser, R.J., Srivastava, A., Tsimilli, M. (2000). The fluorescence transient as a tool to characterize and screen photosynthetic samples. In: Probing photosynthesis: mechanisms, regulation and adaptation. Taylor and Francis, New York, London, pp. 445-483.

Sullivan, J. H., \& Teramura, A. H. (1990). Field study of the interaction between solar ultraviolet-B radiation and drought on photosynthesis and growth in soybean. Plant Physiology, 92, 141-146.

Thomas, H., \& James, A. R. (1999). Partitioning of sugars in Lolium perenne (perennial ryegrass) during drought and on rewatering. New Phytologist, 142, 295-305.
Trzaskoś, M., Czyż, H., Kitczak, T., \& Michałkiewicz, J. (2001). Protein and makroelement content in sward of a seaside meadow on the background of various habitats. Pam. Put., 125, 147-157.

Turner, L. R., Holloway-Phillips, M. M., Rawnsley, R. P., Donaghy, D. J., \& Pembleton, K. G. (2012). The morphological and physiological responses of perennial ryegrass (Lolium perenne L.), cocksfoot (Dactylis glomerata L.) and tall fescue (Festuca arundinacea Schreb. syn. Schedonorus phoenix Scop.) to variable water availability. Grass and Forage Science, 67, 507-518.

Van Soest, P. J., Robertson, J. B., \& Lewis, B. A. (1991). Methods for dietary fiber, neutral detergent fiber, and nonstarch polysaccharides in relation to animal nutrition. Journal of Dairy Science, 74(10), 3583-3597.

Volaire, F. H. Thomas, \& Leliévre, F. (1998). Survival and recovery of perennial forage grasses under prolonged Mediterranean drought: I. Growth, death, water relations and solute content in herbage and stubble. New Phytologist, 140, 439-449.

Volaire, F., \& Thomas, H. (1995). Effects of drought on water relations, mineral uptake, water soluble carbohydrate accumulation and survival of two contrasting populations of cocksfoot (Dactylis glomerata L.). Annals of Botany, 75, 513-524.

Weidner, S., Karamać, M., Amarowicz, R., Szypulska, E., \& Golgowska, A. (2007). Changes in composition of phenolic compounds and antioxidant properties of Vitis amurensis seeds germinated under osmotic stress. Acta Physiologiae Plantarum, 29, 238-290.

Wiseman, H. G., Mallack, J. C., \& Jacobson, W. C. (1960). Determination of sugars in silages and forages. Journal of Agricultural and Food Chemistry, 8, 78-80.

Xu, Z. Z., \& Zhou, G. S. (2005). Effects of water stress and high nocturnal temperature on photosynthesis and nitrogen level of a perennial grass Leymus chinensis. Plant and Soil, 269, 131-139. 